\title{
Annual pollen traps reveal the complexity of climatic control on pollen productivity in Europe and the Caucasus
}

\author{
W. O. van der Knaap · Jacqueline F. N. van Leeuwen · Helena Svitavská-Svobodová • \\ Irena A. Pidek • Eliso Kvavadze • Maia Chichinadze • Thomas Giesecke • \\ Bogusław Michał Kaszewski • Florencia Oberli • Laimdota Kalnina • \\ Heather S. Pardoe • Willy Tinner • Brigitta Ammann
}

Received: 19 November 2009/ Accepted: 21 March 2010

(C) The Author(s) 2010. This article is published with open access at Springerlink.com

\begin{abstract}
Annual PAR (pollen accumulation rates; grains $\mathrm{cm}^{-2}$ year $^{-1}$ ) were studied with modified Tauber traps situated in ten regions, in Poland (Roztocze), the Czech Republic (two regions in Krkonoše, two in Šumava), Switzerland (4 regions in the Alps), and Georgia (Lagodekhi). The time-series are 10-16 years long, all ending in 2007. We calculated correlations between pollen data and climate. Pollen data are PAR summarized per region (4-7 traps selected per region) for each pollen type (9-14
\end{abstract}

Communicated by F. Bittmann.

W. O. van der Knaap $(\bowtie)$ J. F. N. van Leeuwen · F. Oberli · W. Tinner $\cdot$ B. Ammann

Institute of Plant Sciences and Oeschger Centre For Climate

Change Research, University of Bern, Altenbergrain 21,

3013 Bern, Switzerland

e-mail: Pim.vanderKnaap@ips.unibe.ch

J. F. N. van Leeuwen

e-mail: Jacqueline.vanLeeuwen@ips.unibe.ch

F. Oberli

e-mail: pfoberli@bluewin.ch

W. Tinner

e-mail: Willy.Tinner@ips.unibe.ch

B. Ammann

e-mail: Brigitta.Ammann@ips.unibe.ch

H. Svitavská-Svobodová

Institute of Botany, Academy of Sciences of the Czech Republic,

Castle 252 43, Průhonice, Czech Republic

e-mail: svitavska@ibot.cas.cz

I. A. Pidek · B. M. Kaszewski

Institute of Earth Sciences, Maria Curie-Skłodowska University

in Lublin, al Kraśnicka 2 c/d, 20-718 Lublin, Poland

e-mail: i.pidek@ poczta.umcs.lublin.pl

B. M. Kaszewski

e-mail: boguslaw.kaszewski@ poczta.umcs.lublin.pl per region) using log-transformed, detrended medians. Climate data are monthly temperature and precipitation measured at nearby stations, and their averages over all possible 2- to 6-month windows falling within the 20-month window ending with August, just prior to the yearly pollen-trap collection. Most PAR/climate relationships were found to differ both among pollen types and among regions, the latter probably due to differences among the study regions in the habitats of plant populations. Results shared by a number of regions can be summarized as follows. Summer warmth was found to enhance

E. Kvavadze - M. Chichinadze

Institute of Paleobiology, National Museum of Georgia,

Niagvris 4, 0108 Tbilisi, Georgia

e-mail: ekvavadze@mail.ru

M. Chichinadze

e-mail:maizdr@yahoo.com

T. Giesecke

Albrecht-von-Haller-Institute for Plant Sciences, Department of Palynology and Climate Dynamics, University of Göttingen,

Untere Karspüle 2, 37073 Göttingen, Germany

e-mail: Thomas.Giesecke@biologie.uni-goettingen.de

L. Kalnina

Faculty of Geography and Earth Sciences, University of Latvia, Rainis bvld. 19, Riga 1586, Latvia

e-mail: laimdota.kalnina@lu.lv

H. S. Pardoe

Department of Biodiversity and Systematic Biology, National Museum Wales, Cathays Park, Cardiff CF10 3NP, UK

e-mail: Heather.Pardoe@museumwales.ac.uk 
the following year's PAR of Picea, Pinus non-cembra, Larix and Fagus. Cool summers, in contrast, increase the PAR of Abies, Alnus viridis and Gramineae in the following year, while wet summers promote PAR of Quercus and Gramineae. Wetness and warmth in general were found to enhance PAR of Salix. Precipitation was found to be more important for PAR of Alnus glutinosa-type than temperature. Weather did not have an impact on the PAR of Gramineae, and possibly of Cyperaceae in the same year. Care is advised when extrapolating our results to PAR in pollen sequences, because there are large errors associated with PAR from sediments, due to the effects of taphonomy and sedimentation and high uncertainty in dating. In addition, in pollen sequences that have decadal to centennial rather than near-annual resolution, plant-interaction effects may easily out-weigh the weather signal.

Keywords Pollen monitoring .

Annual pollen accumulation - Influx $\cdot$ Climate .

Europe $\cdot$ Caucasus

\section{Introduction}

The study of pollen deposition with annual pollen traps during long series of years is especially valuable for our understanding of the relationships between the pollen signal on one hand, and plant geography, vegetation, environment, climate and weather on the other (Kvavadze 2001; Tinsley 2001; Tonkov et al. 2001; van der Knaap et al. 2001a; Autio and Hicks 2004; Hicks 1974, 1977, 1985; Gerasimidis et al. 2006; Seppä and Hicks 2006; Barnekow et al. 2007; Jensen et al. 2007; Sjögren et al. 2008). Long time-series of annual pollen trapping are now developing in many European and a few Asian countries, within the scope of the Pollen Monitoring Programme PMP (INQUA working group; http://pmp.oulu.fi/guide.html; Hicks et al. 1996, 1999) first initiated by Sheila Hicks (Oulu, Finland) and under her guidance. This has resulted in numerous publications based on pollen traps in Finland where pollen-trap work started decades ago (Hicks et al. 2004; Räsänen et al. 2004; Hicks and Sunnari 2005; Hicks 2001, 2006). Now that the time-series in many other countries are starting to exceed 10 years we have decided to report on them. Hicks et al. (2001) presented a first overview of spatial variation in arboreal pollen deposition across European PMP sites. Long data series obtained within the framework of PMP could be successfully correlated with annual pollen sums obtained by aerobiological monitoring with the use of Burkard traps and other types of volumetric samplers (Levetin et al. 2000; Oikonen et al. 2005; Pidek et al. 2006; Ranta and Satri 2007; Ranta et al. 2007, 2008a).
This paper deals with the relationships between absolute pollen values and climate variables in four countries in or near Europe. Related papers deal with the relationship between results of pollen traps and surface pollen collected close to the traps (Pardoe et al. 2010), with inter-annual variation and pollen/vegetation relationships of Fagus PAR (Pidek et al. 2010), with absolute pollen productivities of Tertiary relict taxa (Filipova-Marinova et al. 2010), and with composite pollen-dispersal functions (Sjögren et al. 2010). They also deal with the longest pollen-trap timeseries in Europe (Nielsen et al. 2010), tree-line detection with pollen traps and macrofossil traps (Birks and Bjune 2010), while Giesecke et al. (2010) provide an historical overview of the use of pollen traps.

The research questions addressed have interfaces with several neighbouring fields. Examples are phenology, in which the timing of flowering and of leaf bud-burst is studied in relation to meteorological factors in winter and spring (Menzel 2003; Studer et al. 2005), aerobiology, in which the timing and quantities of allergenic pollen are studied (pollen calendar) and their relationships to meteorological factors of the current year (e.g. Rodriguez de la Cruz et al. 2008) and ecophysiology, in which resource allocation is estimated under varying weather conditions in species with and without mast-fruiting (e.g. Ranta et al. 2005). This study also contributes to a better understanding of the relationships between pollen productivity and meteorological parameters (e.g. van der Knaap and van Leeuwen 2003; Kamenik et al. 2009), which is relevant for attempts at reconstructing summer temperature and annual precipitation based on pollen on broad scales in space and time (e.g. Seppä and Birks 2001, 2002; Heikkilä and Seppä 2003; Giesecke et al. 2008).

The aim of this paper is to explore the relationships between climate and annual pollen-trap PAR (influx) for a large selection of pollen types in countries other than Finland with long time-series (10 or more years). PAR (pollen accumulation rates; grains $\mathrm{cm}^{-2}$ year $^{-1}$ ) have advantages over pollen percentages, for instance that PAR does not suffer from percentage distortions (Moore et al. 1991). Pollen traps are exceptional in their capacity to determine PAR in a reliable way, which is hardly ever the case in peat or sediment sections because chronological control is rarely perfect (e.g., Bennett and Hicks 2005; Goslar et al. 2009) and taphonomic processes are often insufficiently understood.

Relatively little is known about the relationships between annual weather conditions and pollen productivity of plant populations in different field situations. The plant populations that produce the pollen collected in our traps grow in a wide range of micro-climatic conditions depending on factors such as elevation and exposure. The habitats of the pollen-source populations may be positioned anywhere in 
the climatic space in which the plants can occur. Furthermore, there is the impact of climatic conditions on the transport of pollen from the source plants to the pollen traps. Due to this complexity, this study is explorative rather than hypothesis-testing. The aim of our interpretation is to provide ideas for hypotheses that might be tested at a later stage, with the use of additional types of field data. We will develop a method for dealing with 'noisy' pollen-trap data, attempt tentative explanations for the relationships revealed, and explore ecological and geographical trends. We will discuss which data and which insights are new, how and why our findings agree or disagree with earlier findings, to what extent our results are useful for palaeo-ecological studies, and which new scientific questions arise. Finally we will present a well founded recommendation as to why this type of work should be continued.

\section{Methods}

Pollen-trap data from Poland, the Czech Republic, Switzerland and Georgia are used in this paper to establish pollen/climate relationships. The method is essentially a correlation between the 10-16 year time-series of annual pollen accumulation rates (PAR) in modified Tauber traps (henceforward pollen traps, or traps) with monthly temperatures and precipitation of both the year of pollen collection and the previous year. The pollen data are summarized according to ten climatically homogeneous regions in the four countries, prior to statistical correlation. The unit of pollen data is basically PAR (pollen grains $\mathrm{cm}^{-2}$ year $^{-1}$; also referred to as pollen influx); percentages are not used in this study.

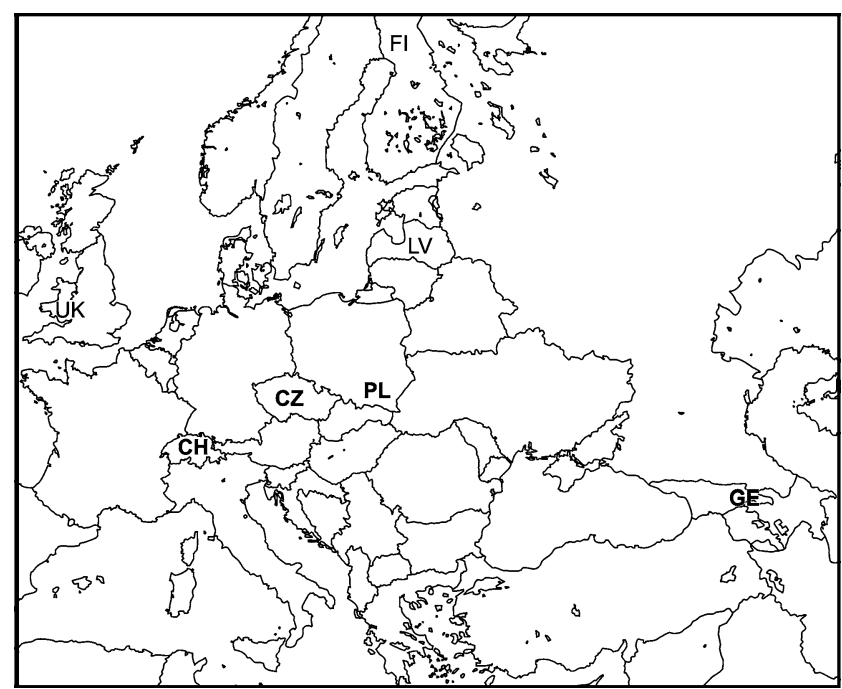

Fig. 1 Map showing pollen-trap countries. $\mathrm{CH}-$ Switzerland; $\mathrm{CZ}-$ Czech Republic; LV-Latvia; PL-Poland; FI-Finland; GEGeorgia; UK-Great Britain; see Table 1 for the regions within the countries

Pollen-data collection

Annual pollen accumulation rates were monitored with pollen traps following the PMP guidelines (Hicks et al. 1996, 1999). Table 1 lists details of the pollen trap regions in the different countries. The length of the time-series varies from 10 to 16 years, all ending with the year 2007 . Initially, data from six countries were considered; two countries (Latvia; U.K.) have been dropped as the pollen data were inconsistent or incomplete (Fig. 1). A selection of pollen types was used, which differs among the study regions (Fig. 2). A pollen type was selected for use when it

Table 1 Pollen-trap regions; PL Poland, CZ Czech Republic (Czech mountains), CH Switzerland (Swiss Alps), GE Georgia (Caucasus), LV Latvia, UK Great Britain (Wales)

\begin{tabular}{|c|c|c|c|c|c|c|}
\hline \multirow{2}{*}{ Country } & \multicolumn{2}{|c|}{ Pollen-trap region (abbr-full name) } & \multirow{2}{*}{$\frac{\text { Latitude }\left({ }^{\circ} \mathrm{N}\right)}{50.5812}$} & \multirow{2}{*}{$\frac{\text { Longitude }\left({ }^{\circ} \mathrm{E}\right)}{23.0604}$} & \multirow{2}{*}{$\begin{array}{l}\text { Elevation of traps (m a.s.1.) } \\
300 \pm 50\end{array}$} & \multirow{2}{*}{$\begin{array}{l}\text { Pollen analyst } \\
\text { IP }\end{array}$} \\
\hline & ROZ & Roztocze & & & & \\
\hline $\mathrm{CZ}$ & KRE & E Krkonoše & 50.73 & 15.77 & $1,150 \pm 450$ & HS-S \\
\hline $\mathrm{CZ}$ & KRW & W Krkonoše & 50.76 & 15.50 & $1,148 \pm 348$ & HS-S \\
\hline $\mathrm{CZ}$ & SUN & N Šumava & 49.09 & 13.40 & $1,095 \pm 295$ & HS-S \\
\hline $\mathrm{CZ}$ & SUS & S Šumava & 48.81 & 13.77 & $1,055 \pm 320$ & HS-S \\
\hline $\mathrm{CH}$ & GRI & Grindelwald & 46.6550 & 8.01 & $2,060 \pm 335$ & JFNvL \\
\hline $\mathrm{CH}$ & ALE & Aletsch & 46.3807 & 8.03 & $2,110 \pm 110$ & JFNvL \\
\hline $\mathrm{CH}$ & SIM & Simplon & 46.24 & 8.02 & $1,835 \pm 250$ & JFNvL \\
\hline $\mathrm{CH}$ & ZER & Zermatt & 45.00 & 7.78 & $2,620 \pm 380$ & JFNvL \\
\hline GE & LAG & Lagodekhi & 41.91 & 46.33 & $1,350 \pm 950$ & EK, MC \\
\hline $\mathrm{LV}^{2}$ & LAT & Latvia & 56.70 & 24.37 & $95 \pm 90$ & LK \\
\hline $\mathrm{UK}^{2}$ & CAP & Capel Curig & 53.09 & $3.90\left({ }^{\circ} \mathrm{W}\right)$ & $320 \pm 180$ & HP \\
\hline
\end{tabular}

\footnotetext{
1 All pollen analysts are co-authors

${ }^{2}$ Data not used; explanation see text
} 
was encountered in all or most pollen traps of a region in all or most years of investigation.

\section{Climate data}

The climate data were obtained from the nearest available meteorological station(s) to the pollen-trap regions. Information on the climate data-sets employed is listed in Table 2. Figure 3 shows the average monthly temperature and precipitation for A.D. 1997-2007 of the climate data-sets concerned. The climate data were not adjusted for altitude according to regional lapse rates, because (1) adjustment has no influence on the climate/pollen correlations made by linear regression, (2) averages of the altitudes of the pollen traps are calculated by region, which would make adjustment somewhat arbitrary, and (3) the altitudes of the pollen traps can differ considerably from the altitude of the pollensource populations, especially due to up-slope pollen transport from lowland taxa in mountain areas.

We used climate data for the same parameters (temperature, precipitation) from two different stations for some regions when it was difficult to decide a priori which station would be more relevant to the pollen-source areas of the traps. In Poland, for example, one station (Zwierzyniec) is located in the slightly elevated study region of Roztocze, whereas the other station (Zamość) lies in a nearby, somewhat rain-sheltered valley. Also, the quality of data may differ among stations, on which we have no further information.

From the monthly values of the original data-sets we calculated multi-month averages of temperature and precipitation sums comprising 2-6 consecutive months. The rationale of this is (a) that the pollen productivity of different plant taxa may depend on weather conditions of different durations, and (b) single-month pollen/climate correlations are more prone to spurious statistical significance, especially for precipitation because it is spatially more variable than temperature. The climate time-series were linearly detrended.

\section{Statistical methods}

The pollen traps are grouped geographically in regions with the same overall climate (Table 1). A common signal for each pollen type in each region was extracted as follows. A selection of traps was used in each region, choosing the longest time-series with the fewest interruptions (Table 3). Therefore time-series of traps that had several years missing or were discontinued after some years due to various forms of disturbance, were not used. In each region, the median yearly PAR of each pollen type was selected. The resulting time-series (one per pollen type per region) were logtransformed and then linearly detrended. Each median PAR value had 1 added, prior to log-transformation, to avoid problems caused by the occurrence of zeros in some of the median PAR time-series.

The statistical software used is PAST v. 1.96 (Hammer et al. 2009). The pollen time-series were tested for normal distribution, autocorrelation and outliers. PAR time-series are Poisson distributed rather than Gaussian, but log transformation followed by detrending makes them close to normally distributed. Autocorrelation in PAR time-series is to be expected, because a year of extremely high pollen production is often followed by a year with low pollen production for physiological rather than climatic reasons. However, after data transformation, no autocorrelation was detected statistically.

Outliers in the pollen time-series might or might not be related functionally to climate. We removed outliers to avoid ambiguity, on the basis of admittedly subjective criteria. Our aim was to create a balance between retaining potential climate signals and removing potentially spurious outliers, as follows.

(1) Outliers were statistically determined using PAST software on log-transformed, detrended time-series. In addition, outliers that were visually detected in normal probability plots were removed to diminish the chance of spurious results.

(2) No more than one outlier was removed per pollen time-series, as outlier removal shortens the timeseries and thus decreases the statistical strength of correlations. (One exception was made, shown in Table 4.)

(3) Where there were several outliers in a pollen timeseries, the most pronounced outlier was selected for removal.

(4) A statistically confirmed outlier was not removed when it lay close to another data point (as visually determined on a normal probability plot). This criterion retained pairs or clusters of outliers, which, because of their joined occurrence, are more likely to be related functionally to weather conditions than isolated outliers.

Annual pollen values are compared to climate data in the 20-month time window prior to pollen-trap collection (extending from January of the year before pollen-trap collection up to, and including, August of the year of pollen-trap collection). Correlations were computed between single pollen types and single climate variables. The climate data considered are temperature and precipitation for all individual months and for all two-, three-, four-, five- and six-month periods falling within the 20month time window. This results in 105 partly overlapping multi-month periods per climate variable (temperature or precipitation). 
Table 2 Climate data; the basic climate data used include average maximum monthly temperature (T) and monthly precipitation sums (P)

\begin{tabular}{|c|c|c|c|c|c|c|}
\hline Country $^{1}$, region ${ }^{1}$, station & Climate station & Data source & Parameter & Latitude $(\mathrm{N})$ & Longitude (E) & Elevation (m a.s.1.) \\
\hline PL ROZ ZWI & Zwierzyniec & $\mathrm{BMK}^{3}$ & $\mathrm{~T}^{7}, \mathrm{P}$ & $50^{\circ} 37^{\prime}$ & $22^{\circ} 58^{\prime}$ & 230 \\
\hline PL ROZ ZAM & Zamość & TuTiempo $^{4}$ & $\mathrm{~T}^{7}, \mathrm{P}$ & $50^{\circ} 42^{\prime}$ & $23^{\circ} 21^{\prime}$ & 213 \\
\hline CZ KRE PEC & Pec pod Snežkou & A.R. ${ }^{5}$ & $\mathrm{~T}, \mathrm{P}$ & $50^{\circ} 40^{\prime}$ & $15^{\circ} 45^{\prime}$ & 820 \\
\hline CZ KRE LIB, CZ KRW LIB & Liberec & A.R..$^{5}$ & $\mathrm{~T}, \mathrm{P}$ & $50^{\circ} 46^{\prime} 09^{\prime \prime}$ & $15^{\circ} 01^{\prime} 30^{\prime \prime}$ & 398 \\
\hline CZ KRW HAR & Harrachov & A.R..$^{5}$ & $\mathrm{~T}, \mathrm{P}$ & $50^{\circ} 45^{\prime} 41.58^{\prime \prime}$ & $15^{\circ} 25^{\prime} 54.38^{\prime \prime}$ & 1,020 \\
\hline CZ SUN CHU & Churáňov & A.R..$^{5}$ & $\mathrm{~T}, \mathrm{P}$ & $49^{\circ} 04^{\prime} 06^{\prime \prime}$ & $13^{\circ} 36^{\prime} 47^{\prime \prime}$ & 1,118 \\
\hline CZ SUN H\&K & Husinec $^{2}$ & A.R..$^{5}$ & $\mathrm{P}$ summer & $49^{\circ} 03^{\prime} 17.85^{\prime \prime}$ & $13^{\circ} 59^{\prime} 13.1^{\prime \prime}$ & 492 \\
\hline CZ SUS H\&K & Klatovy $^{2}$ & A.R..$^{5}$ & $\mathrm{P}$ winter & $49^{\circ} 23^{\prime} 36^{\prime \prime}$ & $13^{\circ} 18^{\prime} 13^{\prime \prime}$ & 430 \\
\hline CZ SUS CER & Černá v Pošumaví & A.R..$^{5}$ & $\mathrm{~T}$ & $48^{\circ} 44^{\prime} 16.66^{\prime \prime}$ & $14^{\circ} 06^{\prime} 40.41^{\prime \prime}$ & 739 \\
\hline $\mathrm{CH}$ GRI ABO & Adelboden & MeteoSwiss $^{6}$ & $\mathrm{~T}$ & $46^{\circ} 29^{\prime} 31^{\prime \prime}$ & $7^{\circ} 33^{\prime} 40^{\prime \prime}$ & 1,320 \\
\hline CH GRI GWD & Grindelwald & MeteoSwiss $^{6}$ & $\mathrm{P}$ & $46^{\circ} 37^{\prime}$ & $8^{\circ} 02^{\prime}$ & 1,158 \\
\hline CH ALE EVO, CH SIM EVO & Evolène-Villaz & MeteoSwiss $^{6}$ & $\mathrm{~T}, \mathrm{P} \mathrm{T}$ & $46^{\circ} 06^{\prime} 44^{\prime \prime}$ & $7^{\circ} 30^{\prime} 31^{\prime \prime}$ & 1,825 \\
\hline CH SIM SIM & Simplon-Dorf & MeteoSwiss $^{6}$ & $\mathrm{P}$ & $46^{\circ} 11^{\prime} 41^{\prime \prime}$ & $8^{\circ} 03^{\prime} 17^{\prime \prime}$ & 1,495 \\
\hline CH ZER ZER & Zermatt & MeteoSwiss $^{6}$ & $\mathrm{~T}, \mathrm{P}$ & $46^{\circ} 01^{\prime} 45^{\prime \prime}$ & $7^{\circ} 45^{\prime} 11^{\prime \prime}$ & 1,638 \\
\hline GE LAG TBI & Tblisi & TuTiempo $^{4}$ & $\mathrm{~T}^{8}$ & $41^{\circ} 40^{\prime}$ & $44^{\circ} 55^{\prime}$ & 467 \\
\hline
\end{tabular}

${ }^{1}$ Country and Region are abbreviated according to Table 1

${ }^{2}$ Climate data of Husinec and Klatovy were combined together $(\mathrm{H} \& \mathrm{~K})$

${ }^{3}$ Co-author

${ }^{4}$ Downloaded from http://www.tutiempo.net/clima/

5 Agrometeorological Rapporteur (1996-2008)

${ }^{6}$ MeteoSchweiz, Zürich $\mathrm{CH}$

7 T 1997 of Zamosc was added to the time series of Zwierzyniec where was not measured in this year (BMK)

8 The $\mathrm{P}$ data have frequent gaps, and no other suitable $\mathrm{P}$ data from Georgia could be traced

The number of calculated correlations depends on the number of pollen types and climate variables per region. It is well known that the number of spurious correlations increases with the number of statistical tests done. A Bonferroni correction would reduce the $P$-value to ca. 0.0005 for a $5 \%$ chance that a correlation is spurious. As the aim of this paper is explorative rather than hypothesis testing, we show all correlations in Fig. 4 that have $P<0.05$, but we are cautious with our interpretations.

We refrain from providing proportions of explained variance. Presenting these would be over-rating the results, because pollen data are noisy, the calculation of the pollen values used in the correlations was complex, and the suitability of the available climate data differs among the pollen-trap regions. Also, the explained variance for precipitation can not be compared to that in temperature because they have different relevance for the pollen-source areas.

\section{Results and interpretation}

The results for each pollen type are shown in Fig. 4. Results for temperature are in the upper section of each diagram, results for precipitation in the lower section. The $y$-axis scale shows the months in the 20-month time window prior to the month of pollen-trap collection, starting at the top with $1=$ January. The horizontal dashed lines separate 3-month seasons, the solid lines separate the years. The first header line indicates the study regions according to Table 1 , the second header line indicates the climate stations according to Table 2, occasionally further abbreviated due to space considerations. Correlations with $P \geq 0.05$ are not shown. Black dots show $P$-values of significant correlations $(P<0.05)$, negative correlations to the left of the central row of grey dots, positive to the right. The weakest correlations ( $P$ close to 0.05 ) are placed closest to the central line, the strongest (approaching $P=0$ ) furthest away from it at the scale limit. For each month, the correlation shown is the strongest (lowest $P$ value) among the results of the overlapping multi-month parameters (6-21 per month). There is one exception; the result for a single-month parameter is not shown if its sign $(+$ or -$)$ is opposite to that for a multi-month parameter in the same month, and no results are shown for months that have both positive and negative results among the multimonth parameters. The number of months of the multimonth parameter used is printed to the right of the curves. 

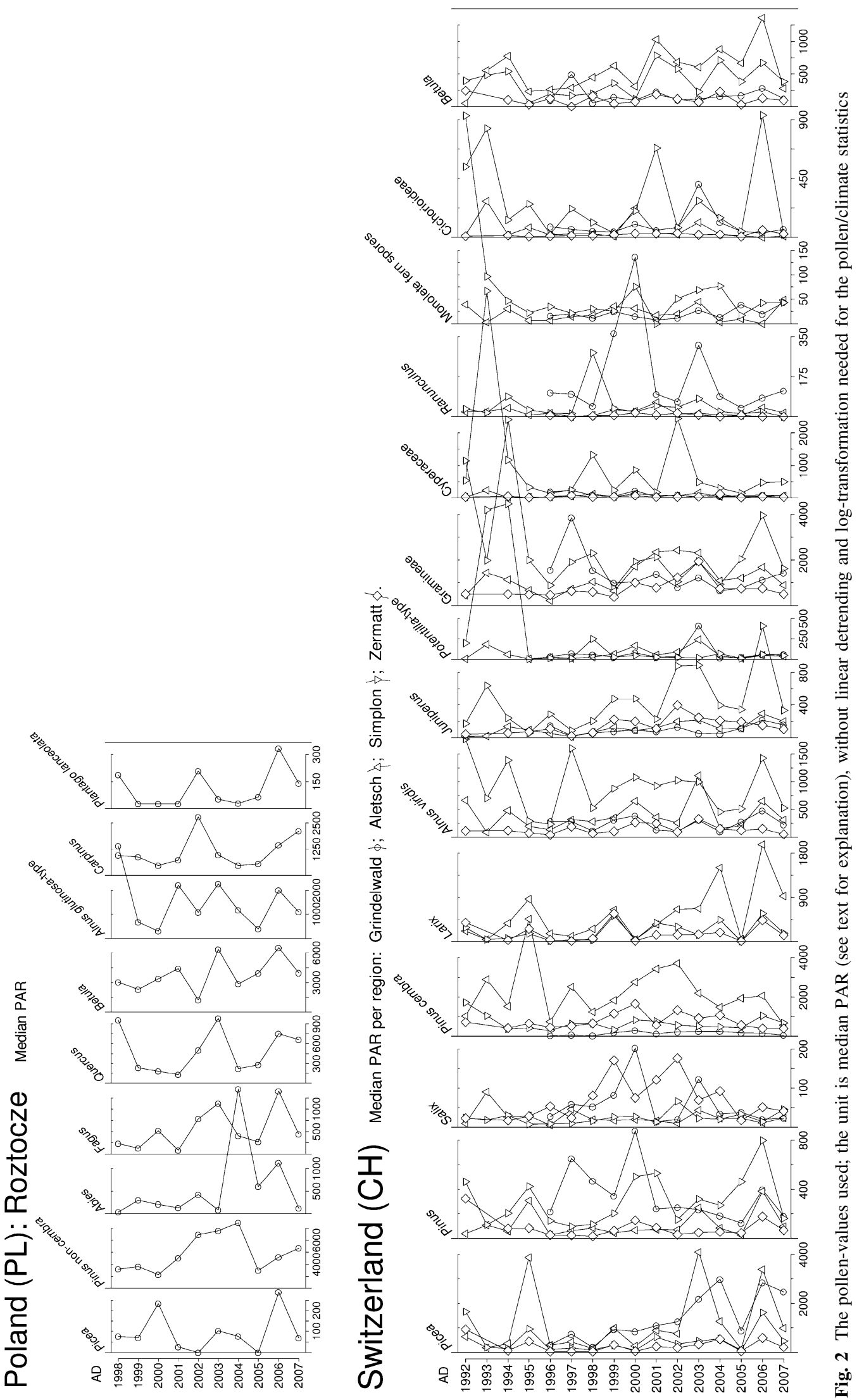


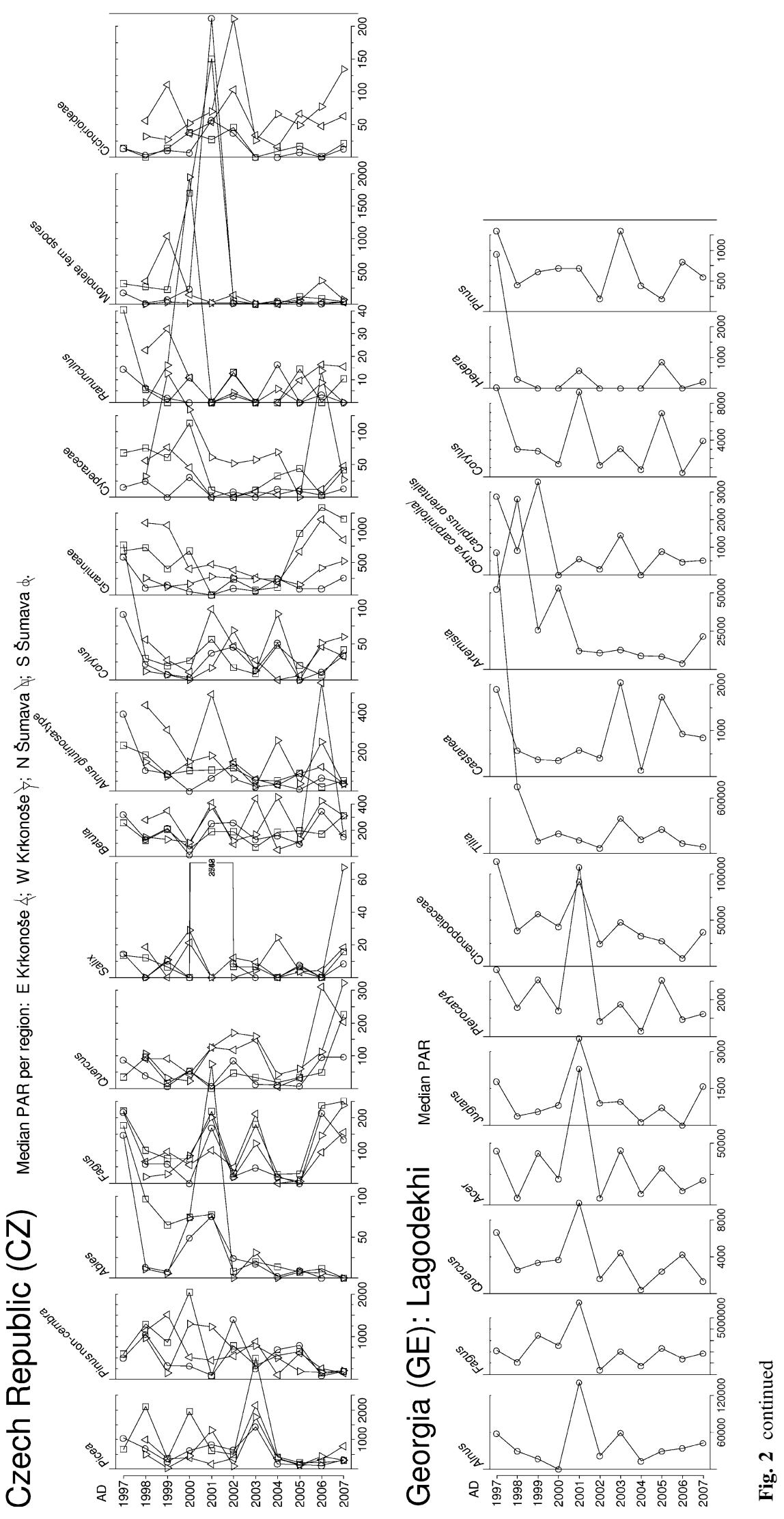



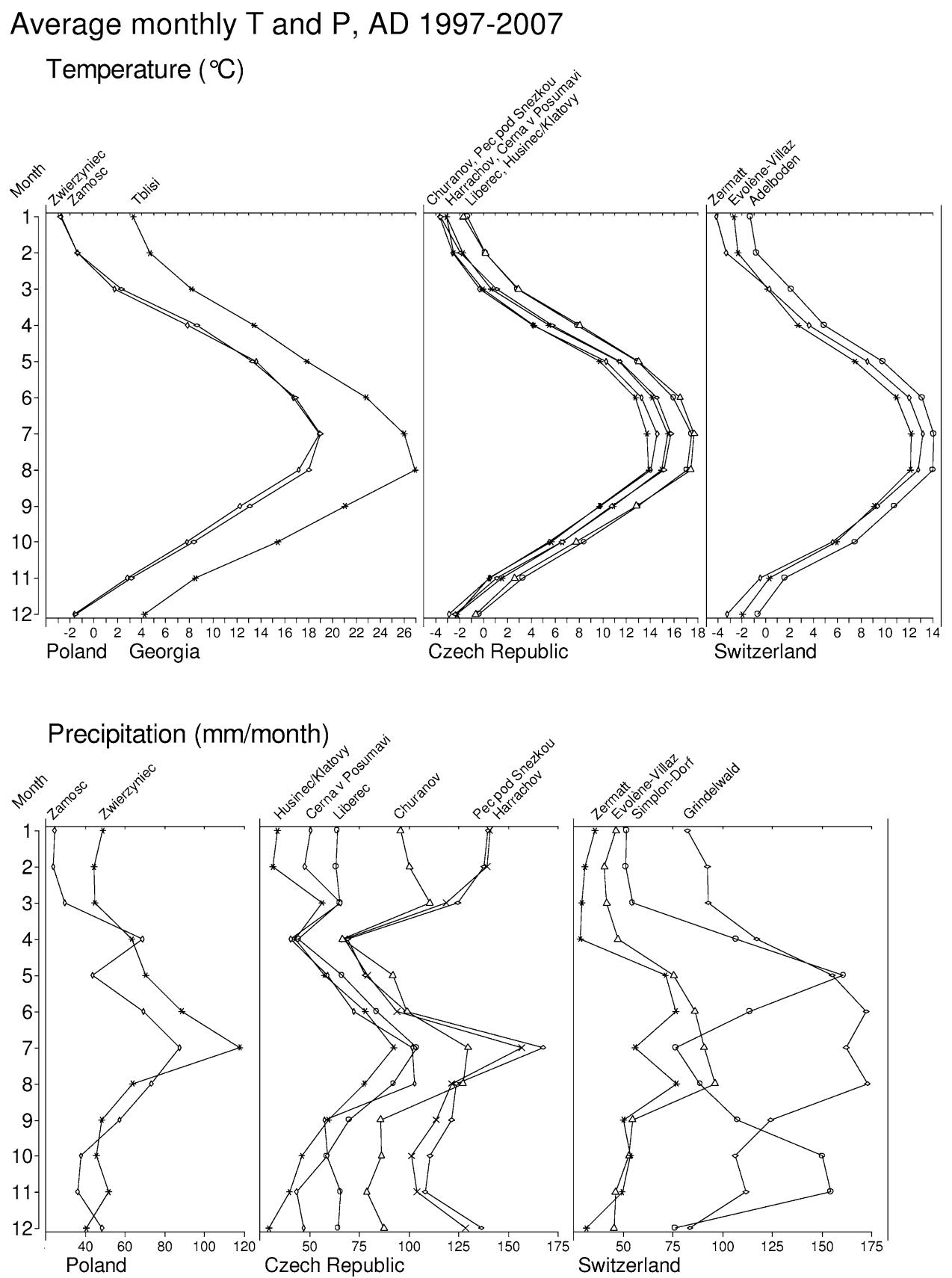

Fig. 3 Average monthly weather conditions for all stations used; see Table 2 for information on climate stations

General aspects

The pollen types used (Fig. 4) can, in many cases, be narrowed down taxonomically for specific regions on the basis of plant geography (presence/absence of taxa in a region). In this analysis, rare occurrences of native taxa and planted or naturalized exotics are not considered. Regionspecific plant taxa are as follows: Picea pollen represents $P$. abies. Pinus non-cembra pollen represents $P$. sylvestris in Poland, both P. sylvestris and P. mugo s.1. in the Czech mountains and the Swiss Alps, and mainly P. kochiana in
Fig. 4 Results: pollen/climate correlations. The upper section of each diagram shows results for temperature, the lower section precipitation. $Y$-axis scale is months in the 20-month time window prior to pollen-trap collection, starting at the top with January (1). Horizontal lines separate 3-month seasons. Study regions are in the first header line (see Table 1); climate stations are in the second header line (see Table 2). Black dots show $P$-values $<0.05$ according to the $X$-axis scale, negative correlations to the left, positive to the right. One $P$-value is shown for each month, selected among results of overlapping multi-month parameters according to rules explained in the text. The number of months of the multi-month parameter used is printed to the right of the curves. Abbreviations: Su.—Šumava; Krk., Krkon.-Krkonoše; Lag.-Lagodekhi; Ostr. c./Carp. o.—Ostrya carpinifolia/Carpinus orientalis 


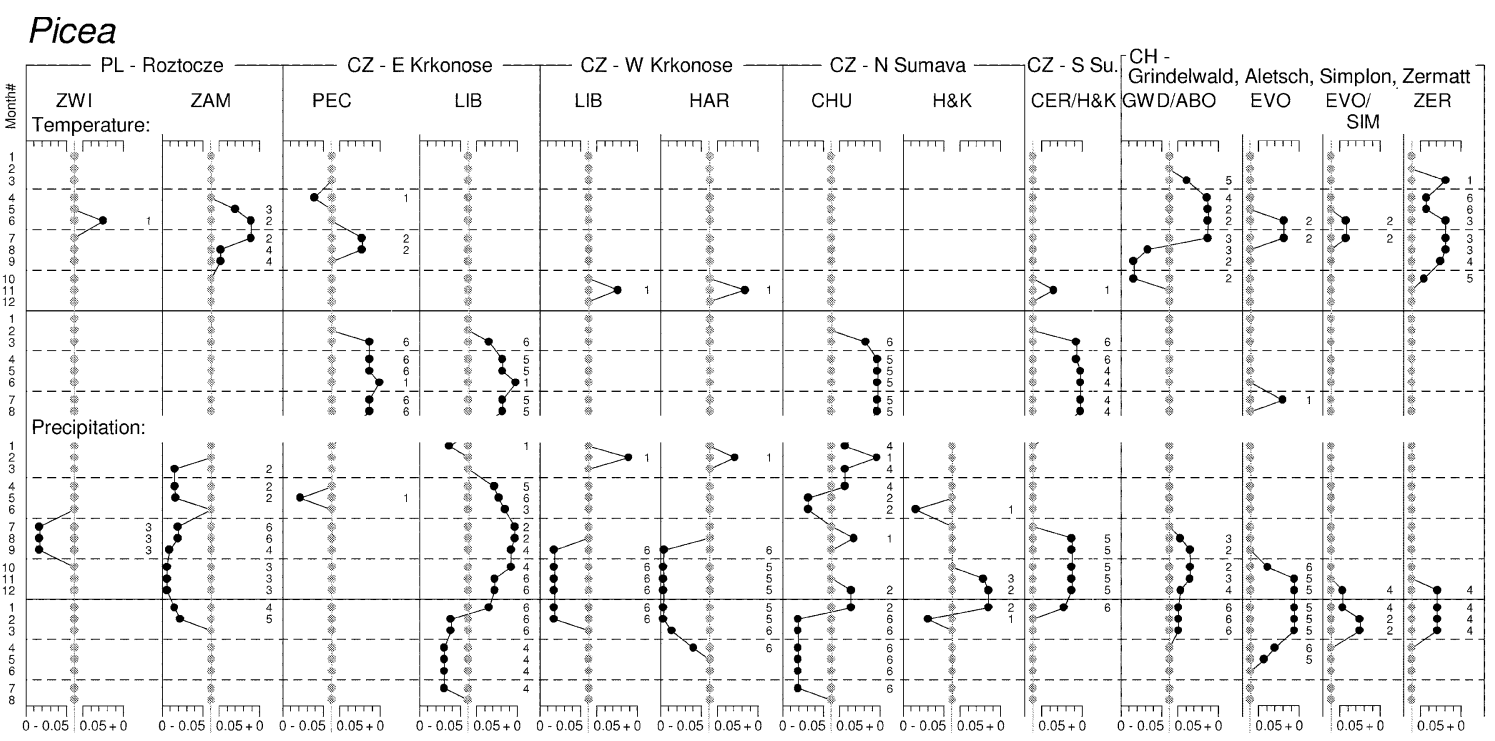

Pinus non-cembra

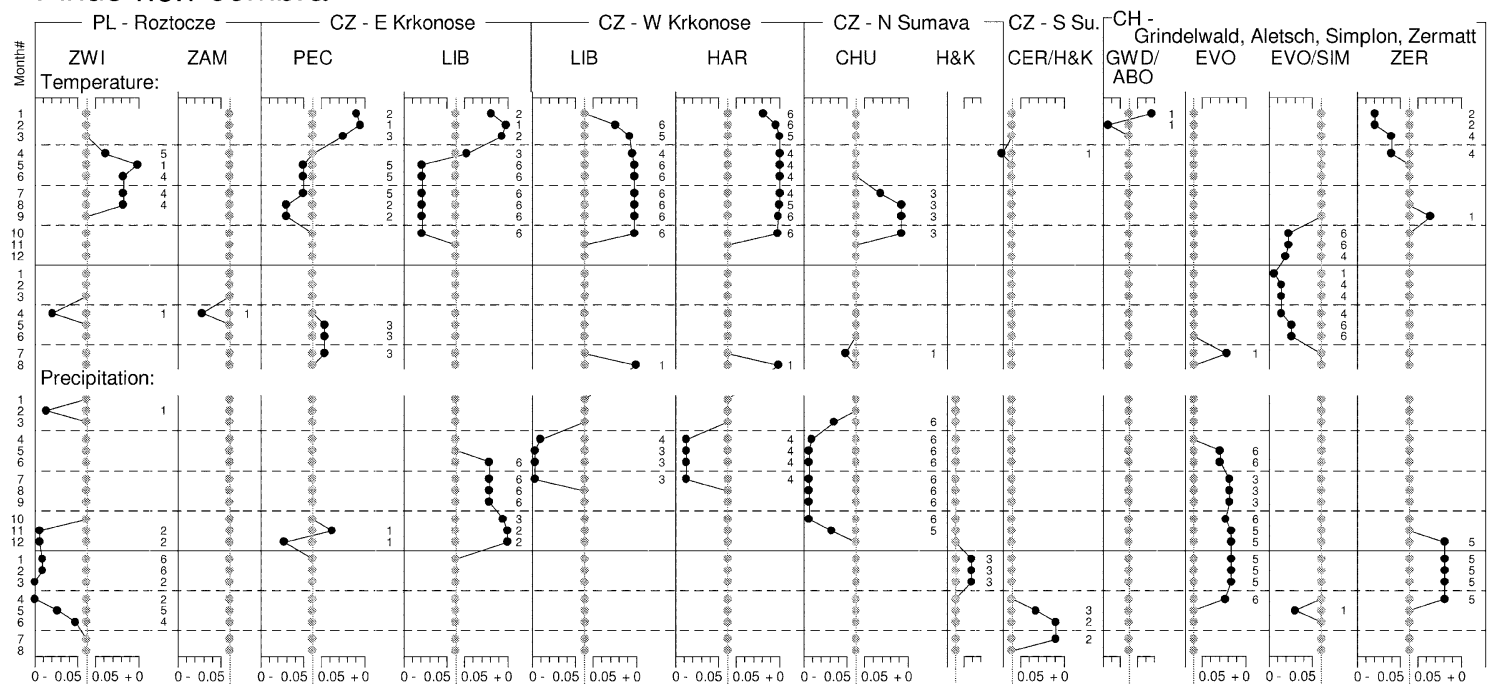

Abies

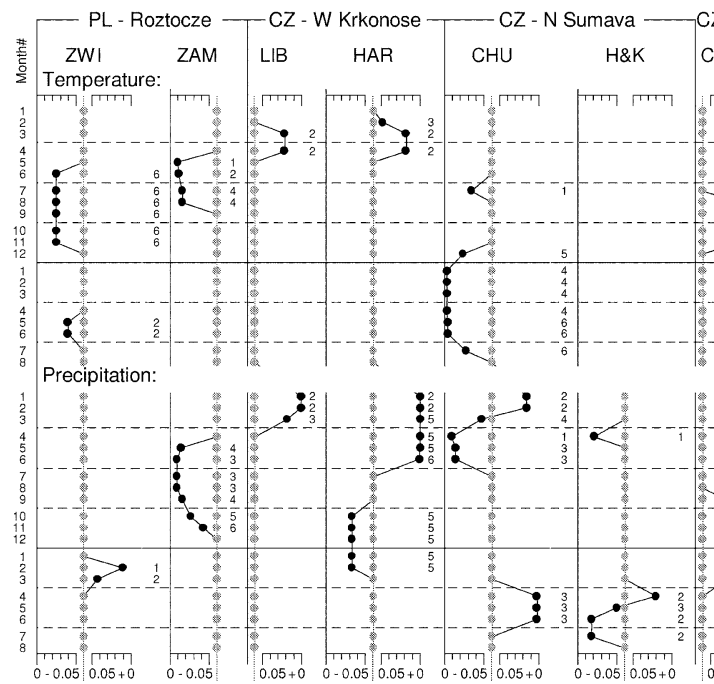

Pinus cembra

Larix

$\mathrm{CZ}$ - S Su.- $\mathrm{CH}$ - Grindelwald, Aletsch, Simplon, Zermatt $-\mathrm{CH}$ - Aletsch, Simplon, Zermatt CER/H\&K GWD/ABO EVO EVO/SIM ZER EVO EVO/M ZER

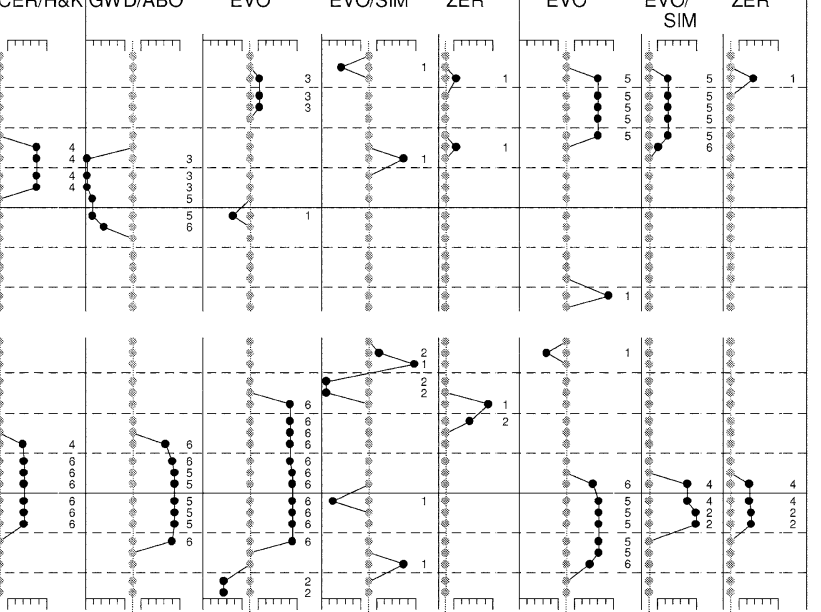



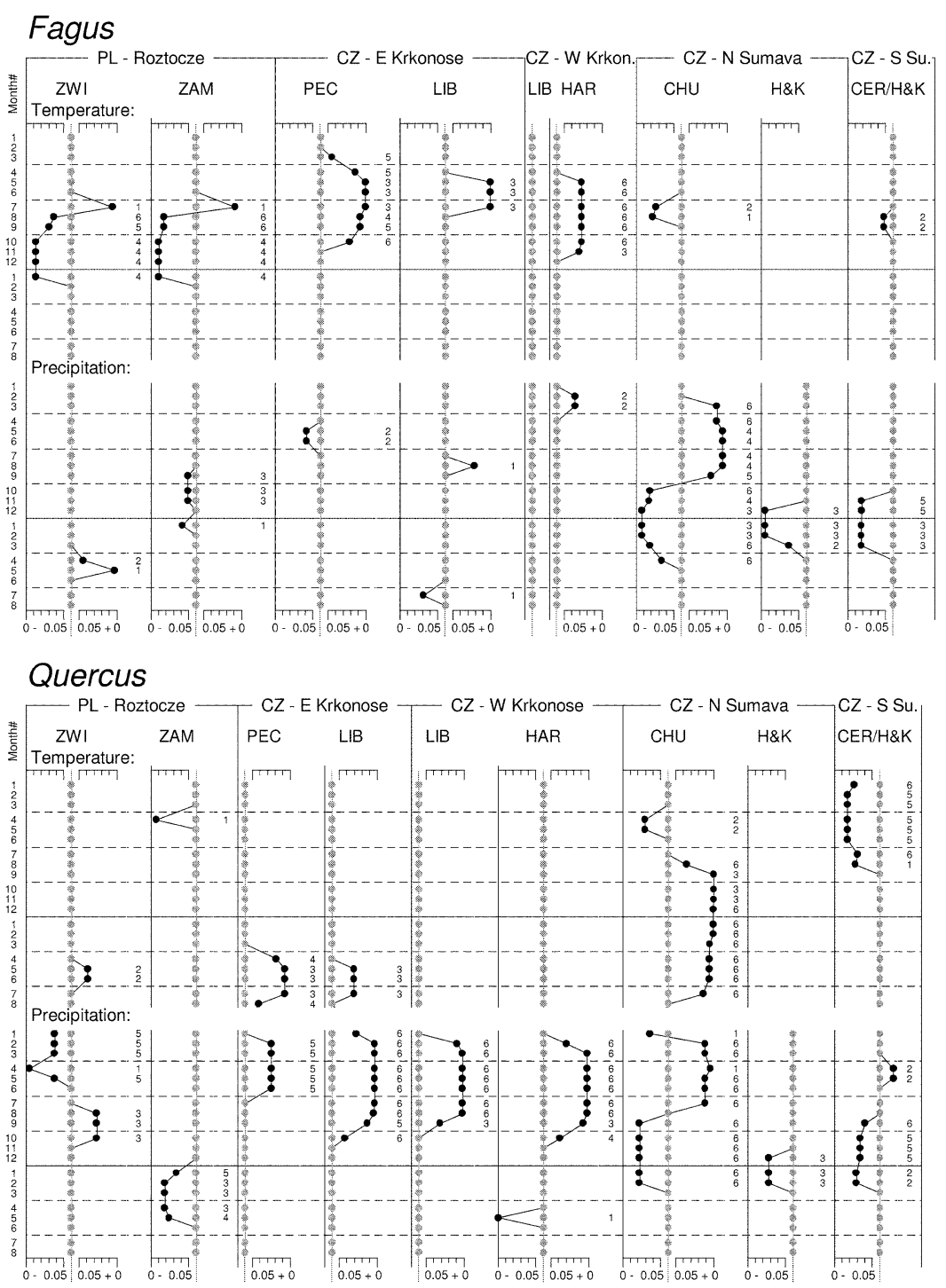

Salix

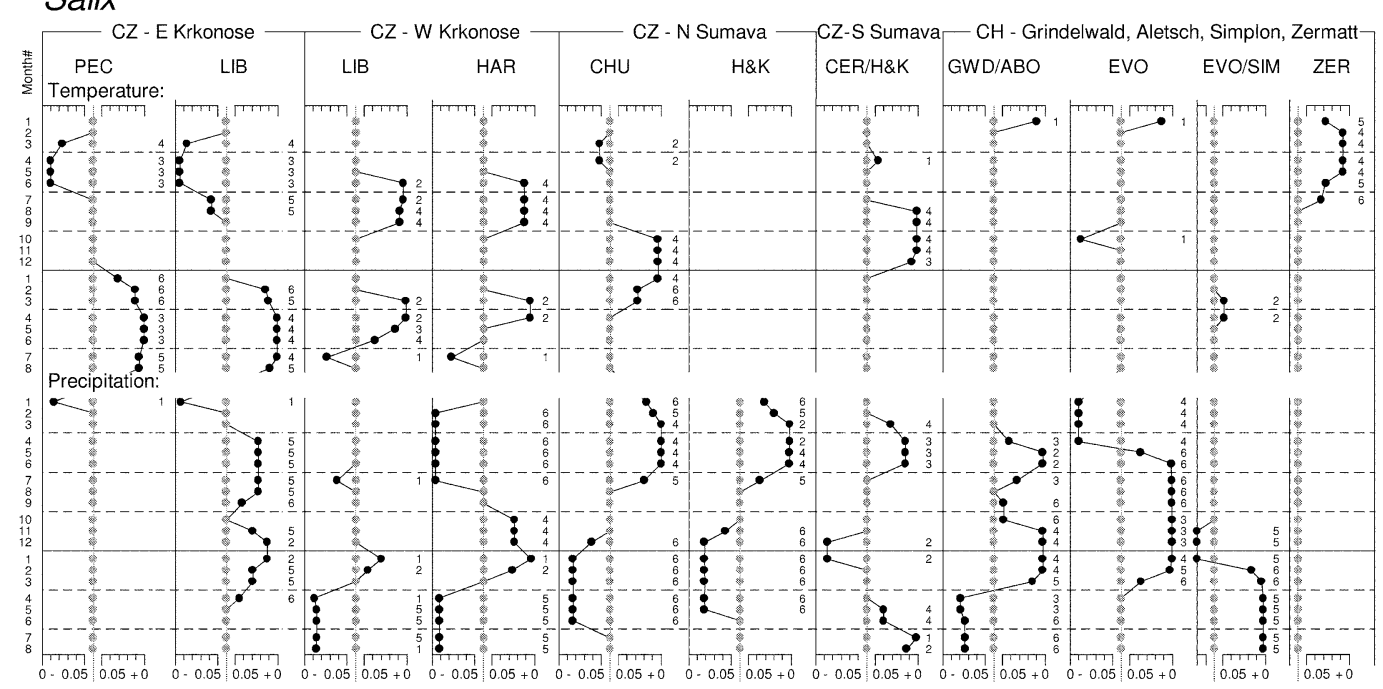

Fig. 4 continued 


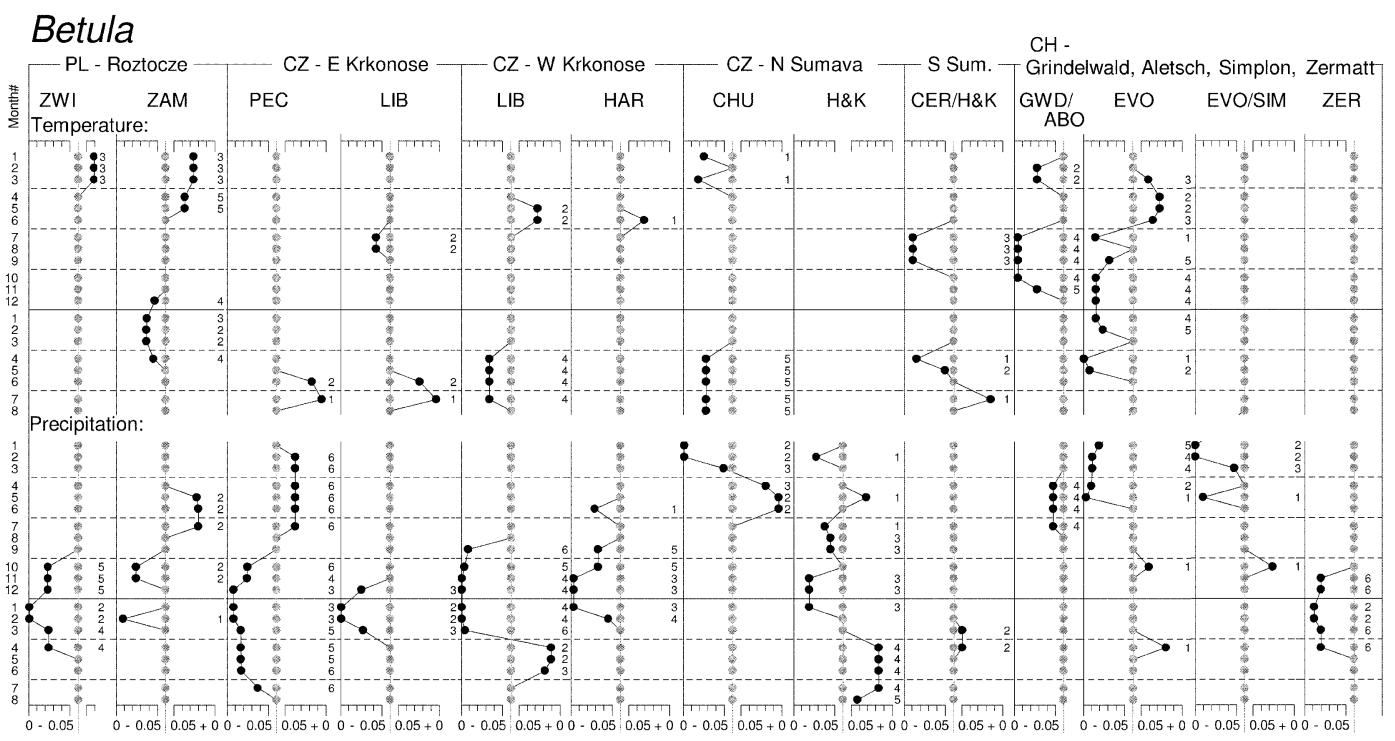

\section{Alnus glutinosa-type}

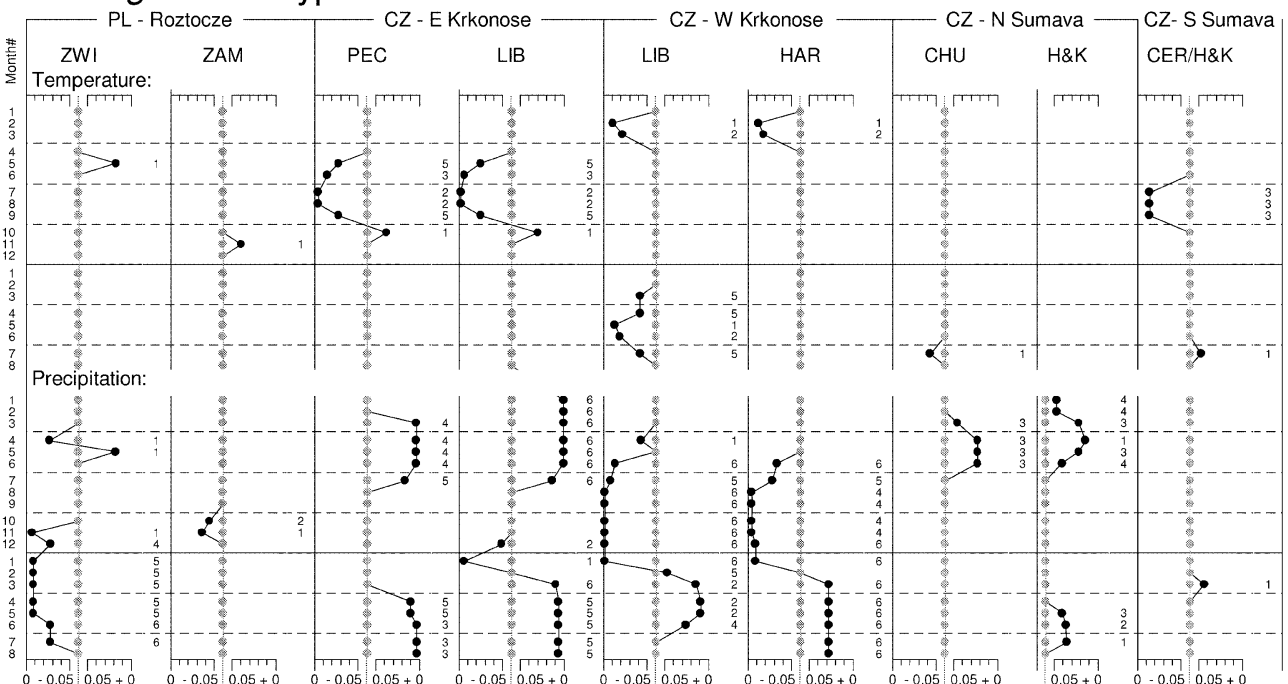

Corylus

Alnus viridis

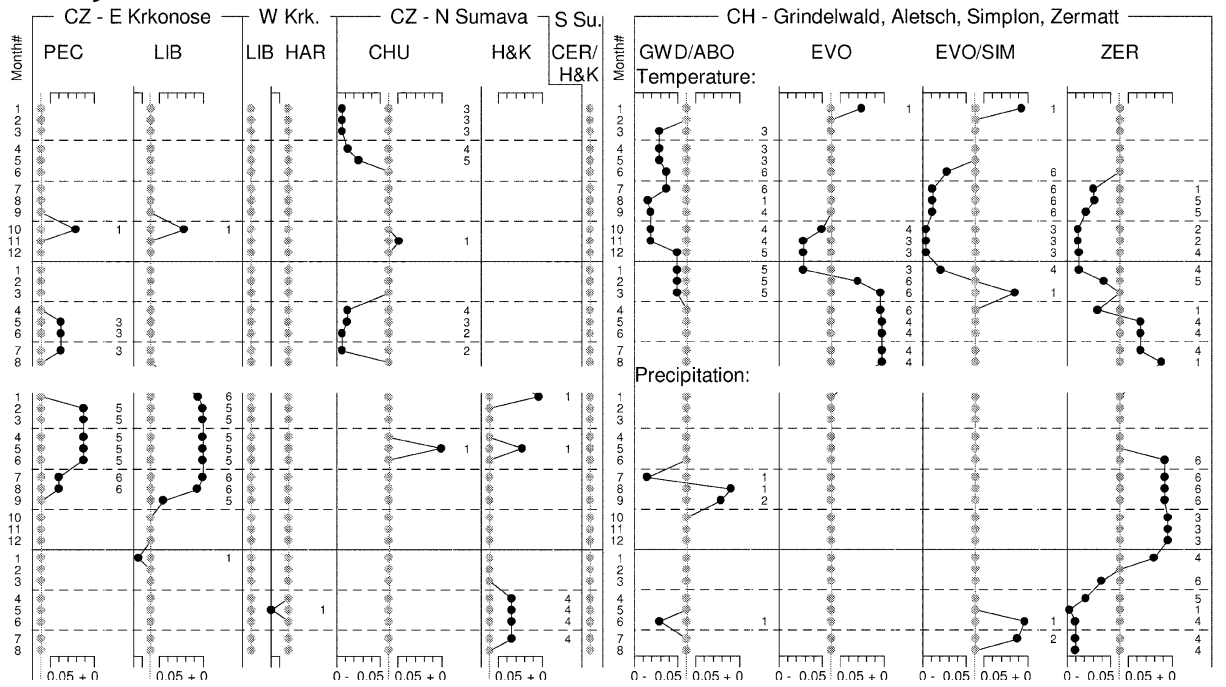

Fig. 4 continued 


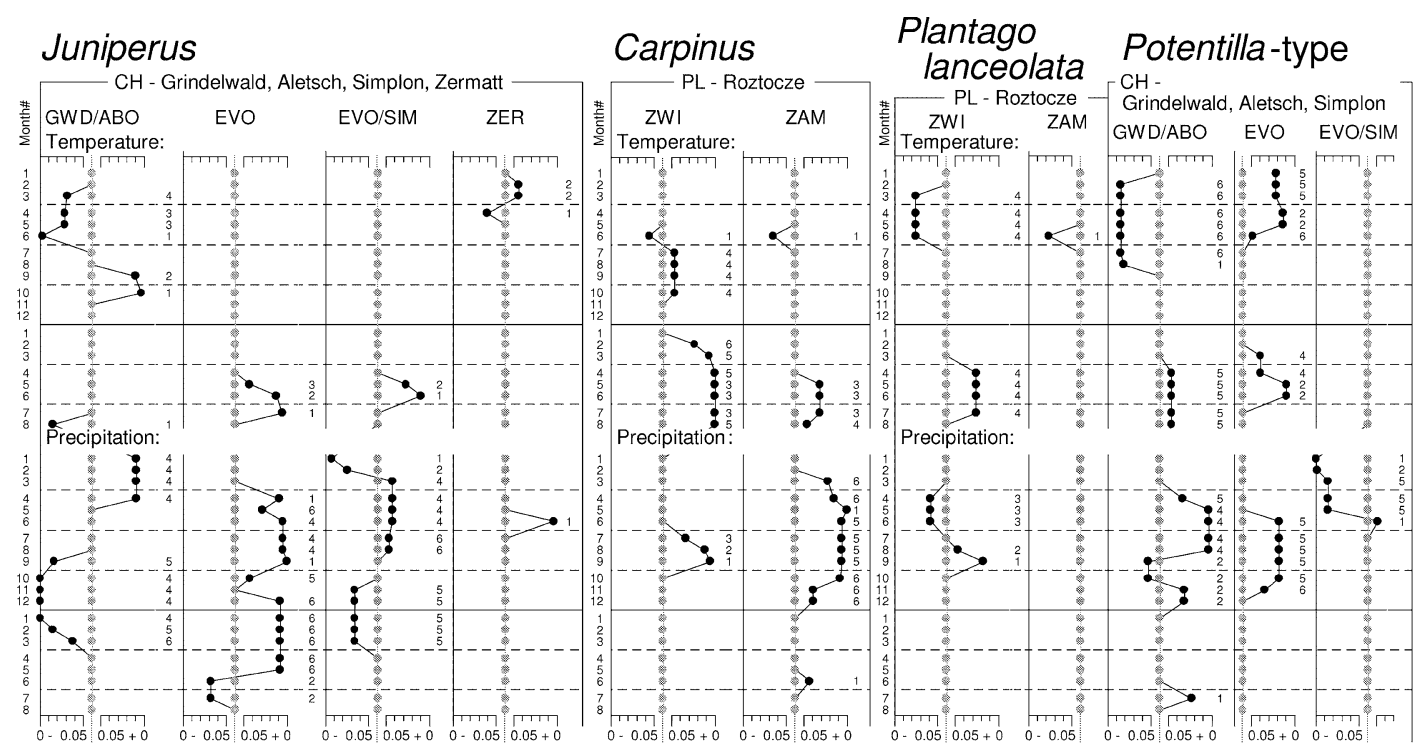

\section{Gramineae}

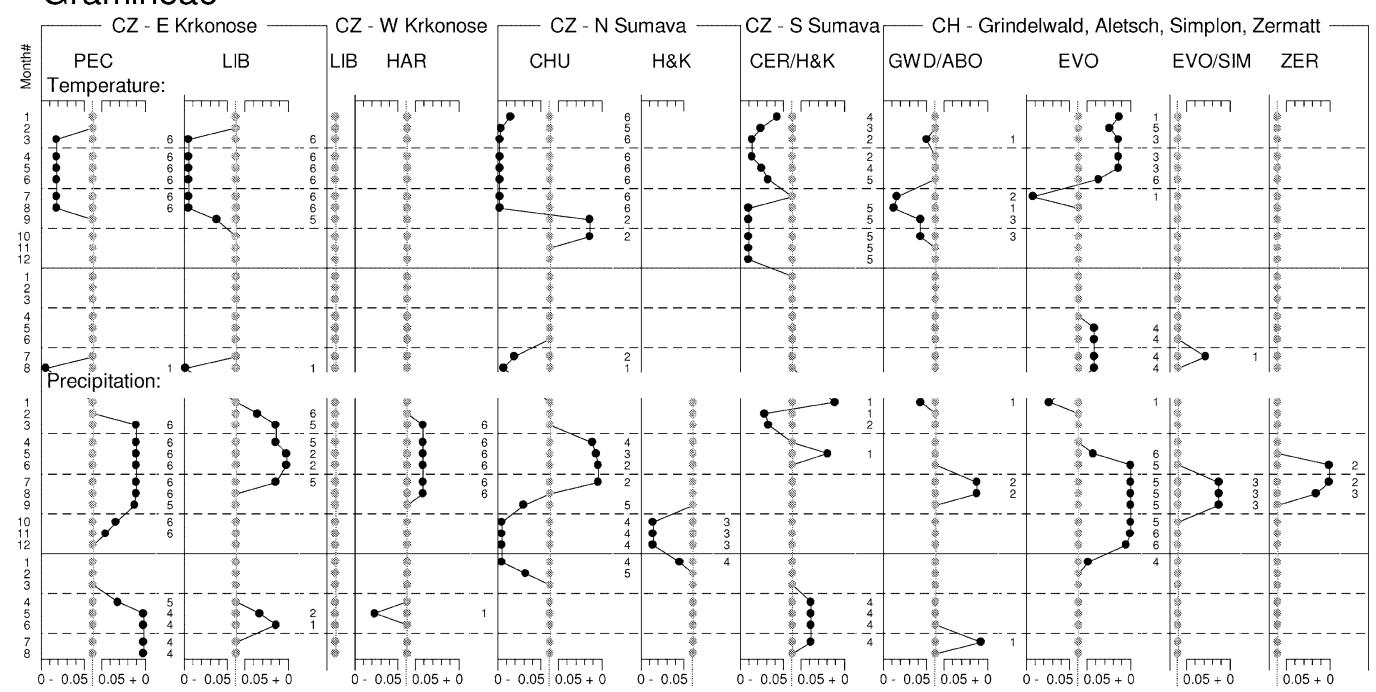

\section{Cyperaceae}

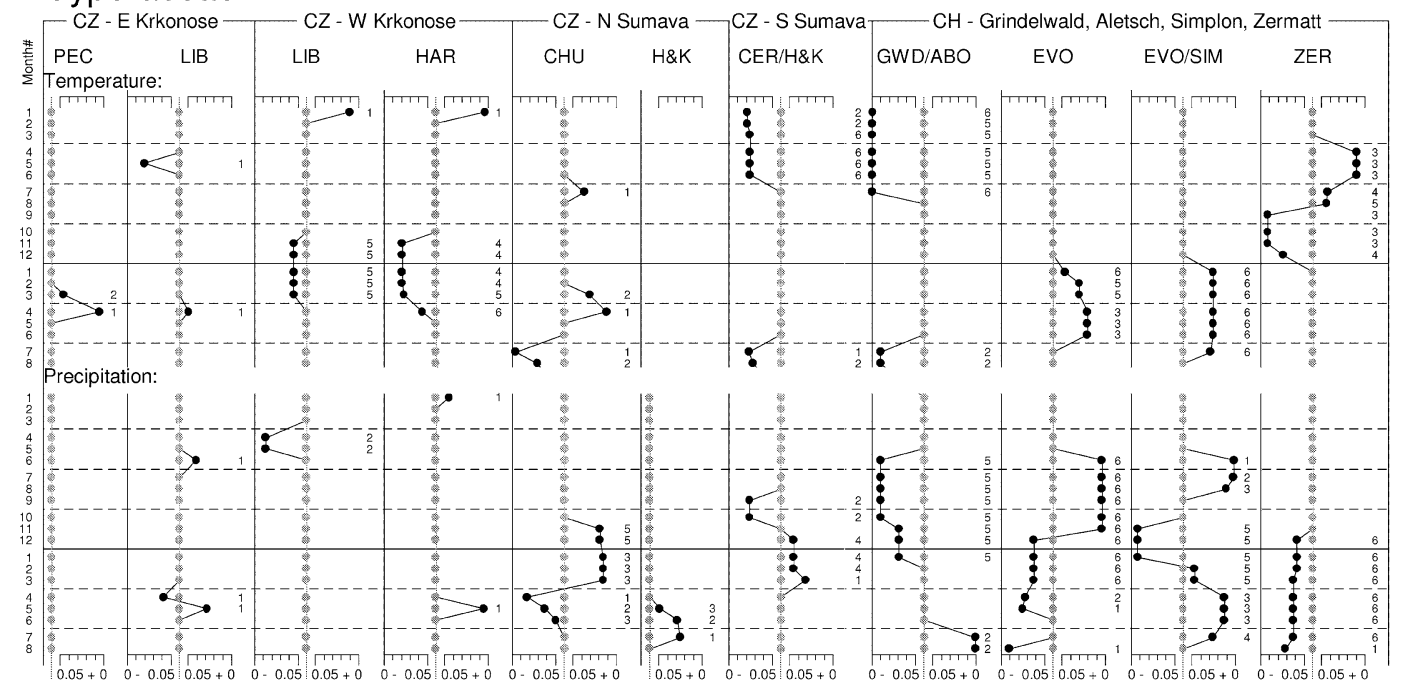

Fig. 4 continued 


\section{Ranunculus}

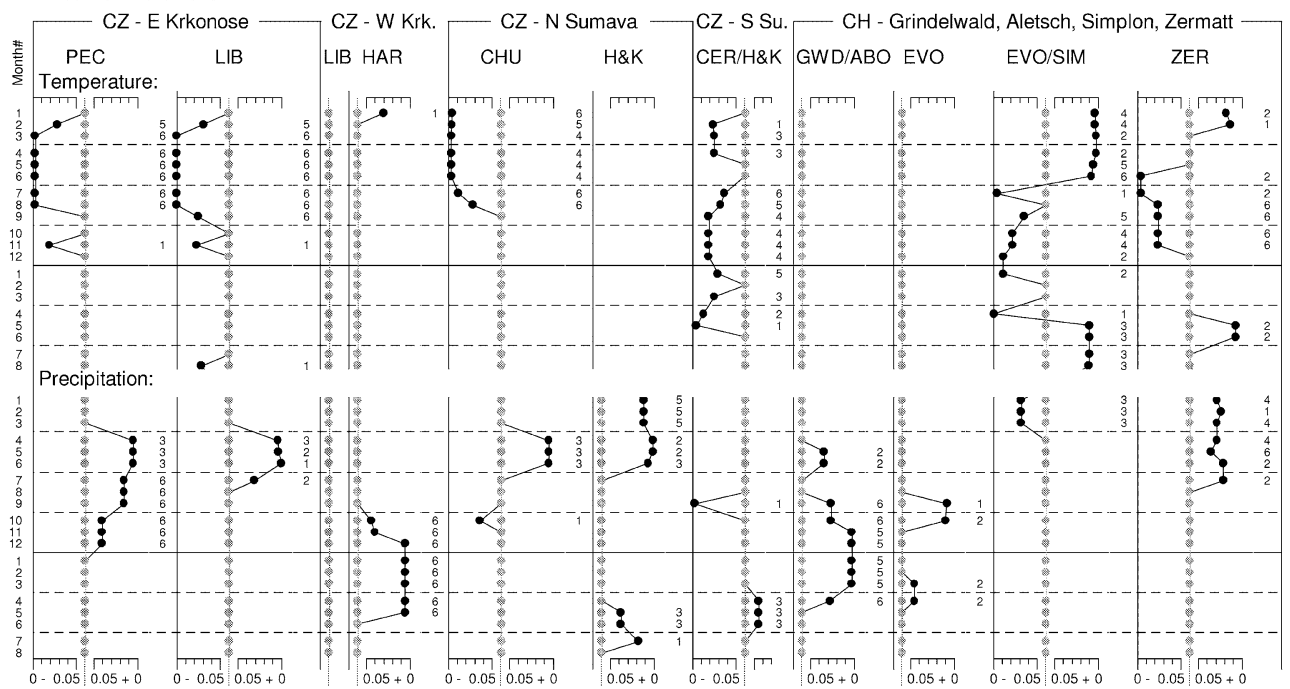

Monolete fern spores

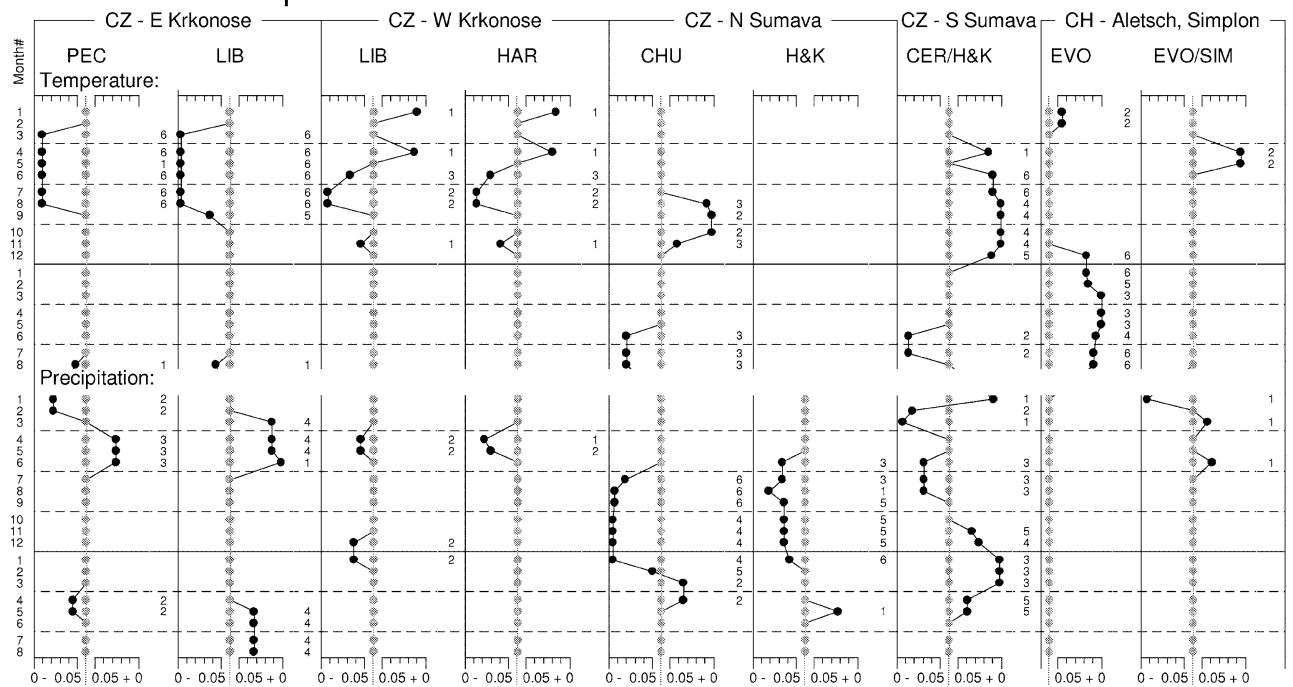

\section{Cichorioideae}

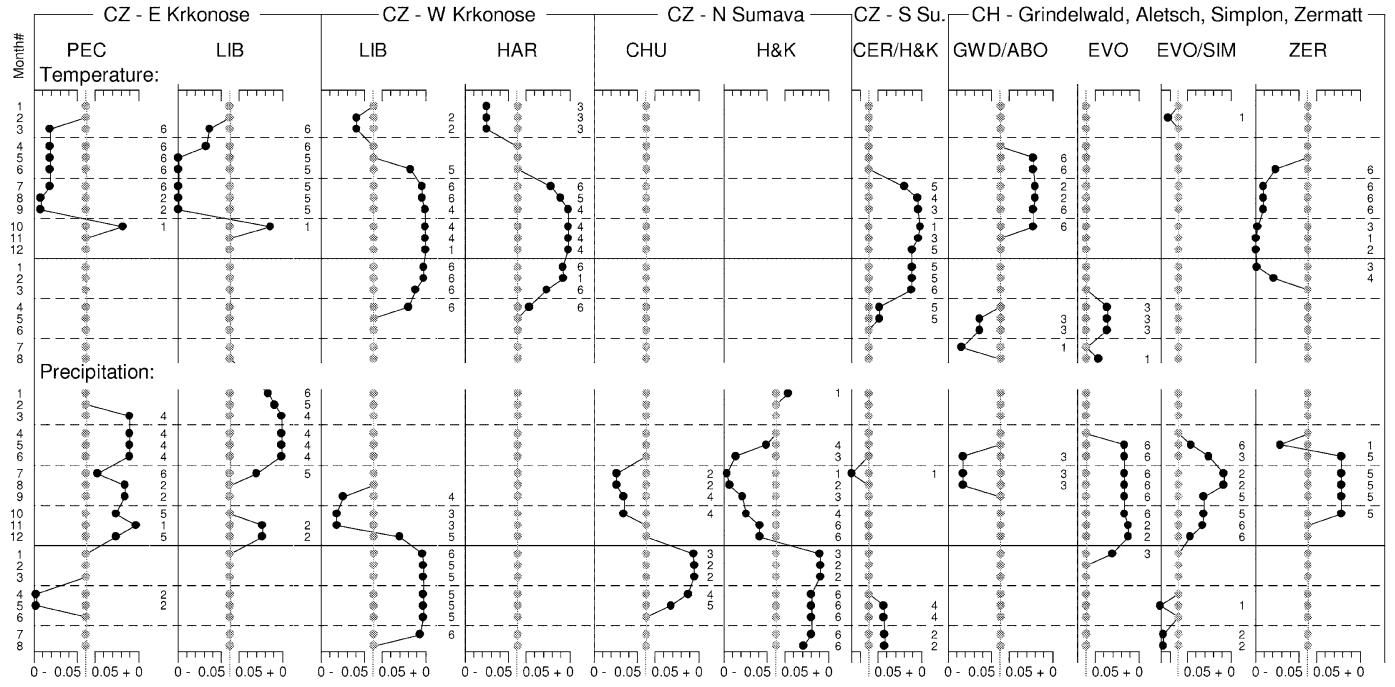

Fig. 4 continued 


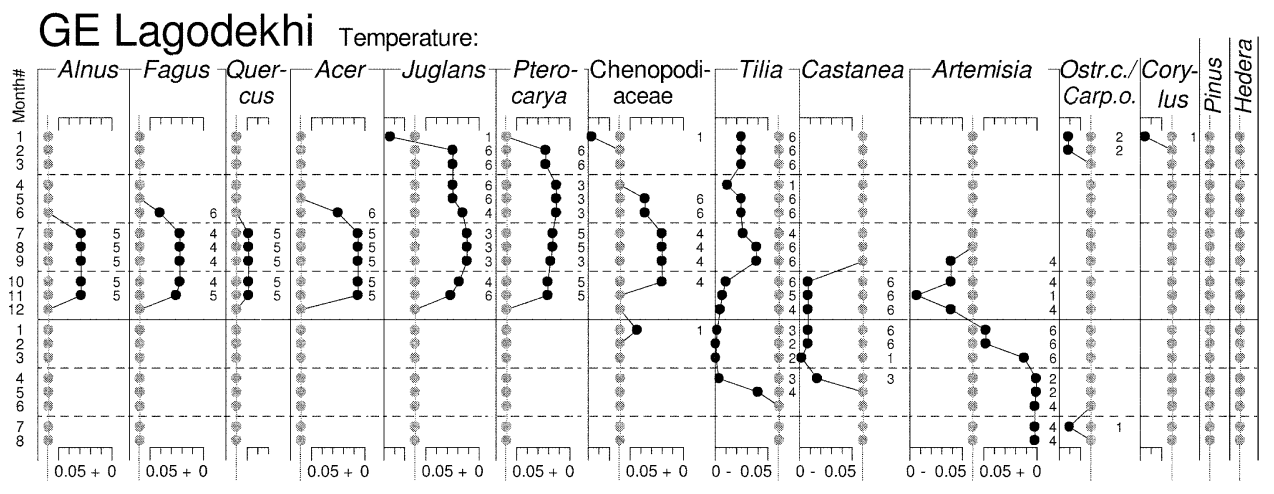

Fig. 4 continued

Georgia; other species are subordinate. Abies pollen represents A. alba. Juniperus pollen in the Swiss Alps represents mostly $J$. communis ssp. alpina (=nana), but may have an unknown admixture of $J$. sabina pollen in Aletsch and Zermatt in particular. Fagus pollen represents $F$. sylvatica in Poland and the Czech mountains and the closely related $F$. orientalis in Georgia. Quercus pollen represents $Q$. robur and $Q$. petraea in Poland and the Czech mountains and mainly $Q$. iberica in Georgia. Betula pollen represents the tree-birches $B$. pubescens and $B$. pendula; other birch species are too rare to play a role. Corylus pollen represents $C$. avellana. Alnus glutinosa-type pollen represents $A$. glutinosa in Poland, both A. glutinosa and $A$. incana in the Czech mountains, and both $A$. barbata and A. incana in Georgia. Tilia pollen in Georgia represents mainly $T$. begoniifolia and $T$. cordata. Castanea pollen represents $C$. sativa. Cyperaceae pollen derives mostly from mire plants in the Czech mountains, and from plants in various divergent habitats in the Swiss Alps. Pterocarya pollen represents $P$. fraxinifolia. Hedera pollen represents $H$. helix. Monolete fern spores represent the taller, summer-green ferns, which have a herbaceous growth-form.

It is good to keep in mind some general features of the growth potentials of the plants involved and their pollen. In all the trees and shrubs studied, the pollen starts to develop and the exact number of pollen grains is determined in the summer or autumn of the year prior to flowering and pollen release. The herbs studied are, as far as we know, temporally less restricted in their pollen initiation, and this is also true of ferns and their spores. Herbs may initiate flower buds in autumn ready to develop in spring, but new buds are initiated and will come to flower during the flowering season (Tyler 2001).

Correlations were calculated for temperature and precipitation separately, even though their effect on pollen may be interrelated. For example, a plant stressed by wet conditions (favoured by drought) will show a negative correlation with precipitation in Fig. 4, but potentially also a positive correlation with temperature, because (a) moisture stress (local wetness) tends to decrease with increased temperatures and (b) temperature and precipitation data tend to be negatively correlated. Similarly, a plant stressed by coldness (favoured by warmth) will yield a positive correlation with temperature, but often also a negative correlation with precipitation. The numerical strength of the correlation (proportion of explained variance) could not be used to determine whether temperature or precipitation is more important for PAR, because trends in temperature are geographically more consistent than trends in precipitation.

Figure 4 shows frequent cases of long series of months yielding the same type of result. A partial explanation might be a stability of weather patterns causing autocorrelation among climate data for consecutive months. If, for example, the weather conditions during only one or a few months are relevant for pollen, the statistical significance may spread to adjacent months that have similar weather conditions. Statistical pollen/climate significance will spread out to more distant months when the correlation is stronger (lower $P$-value). A frequent pattern in the results (Fig. 4), that suggests such a spread of significance, is a sequence of months with the same sign of significant correlation in which the months in the middle of the sequence have a lower $P$-value than the months towards the beginning and end of the sequence. This implies that only the middle months with the lowest $P$-value might be relevant for pollen productivity.

In the results (Fig. 4), the dissimilarity among regions of significant climate/pollen correlations catches the eye. Different regions, even in the same country, produce different results for the same pollen type in many cases. This is likely to be partly spurious, due to the large number of statistical tests conducted, so we will generally ignore correlations that have a $P$-value above about 0.01 . We will tentatively refer to correlations with higher $P$-values (up to about 0.03 ) only when we observe similarities in results among regions. 
A few cases of highly significant correlation occur for trees and shrubs after their flowering period in the year of pollen-trap collection (Salix in two regions; Alnus glutinosa-type, Alnus viridis, Carpinus and Picea in one region). A potential mechanism is re-deposition of pollen released earlier in the year and deposited on the ground or other surfaces. This would require dry, windy weather, which, in our results, would be manifested as negative correlations with precipitation and/or positive correlations with temperature. However, there are both negative and positive correlations among the highly significant post-flowering correlations, both for temperature and precipitation, so this result may be spurious.

Trees and shrubs

\section{Picea $(P L, C Z, C H)$}

For N Finland, Huusko and Hicks (2009) found a good correlation of Picea PAR with warm conditions in July of the year prior to pollen-trap collection. We had similar results for two or three months in the period from June to August in Roztocze (PL), E Krkonoše (CZ), and the four regions of Switzerland $(\mathrm{CH})$. In all regions except two is $P<0.02$. This result indicates that summer warmth also favours pollen production in these regions.

Van der Knaap and van Leeuwen (2003) had similar results on the basis of high-resolution pollen diagrams from mires in Grindelwald $(\mathrm{CH})$ and Aletsch $(\mathrm{CH})$, two regions where pollen traps are also located. They correlated Picea pollen values with measured temperature and precipitation for most of the 20th century, and found that a warm March/ August (Grindelwald) and warm April/August (Aletsch) favoured Picea pollen values.

Warm conditions are indicated in E Krkonoše $(\mathrm{CZ})$ and $\mathrm{N}$ and S Šumava (CZ) for the summer of the year of pollentrap collection. Such conditions apparently favour the release and/or transport of pollen in these regions. It is, however, counter-intuitive that the period of significant correlation extends up to August, the last month prior to pollen-trap collection, after the period of flowering.

Some similarity among regions can be observed in the results for precipitation. High Picea PAR correlates with wet conditions during July/August of the previous year in E Krkonoše (CZ), August/December in S Šumava (CZ), September/November in Grindelwald $(\mathrm{CH})$, and during some months between November and March in the three remaining Swiss areas $(\mathrm{CH})$. The consistent correlation between winter precipitation and high PAR in the four Swiss regions might be tentatively explained by snow insulation preventing winter-frost damage to needles, buds, and the trunk close to the root system (Tranquillini 1979; Körner 1999). These correlations are, however, opposite to the dry conditions indicated in Roztocze (PL) for October/ December and in W Krkonoše (CZ) for September/February. It is unclear to us why precipitation over winter (mostly snow) should affect pollen productivity in most regions, especially since this effect is positive in most regions but negative in others.

\section{Pinus non-cembra (PL, CZ, CH, GE)}

As for Picea, Huusko and Hicks (2009) found that in N Finland warmth in July stimulates pollen productivity in the following year for Pinus sylvestris. We obtained a similar result, but over a longer period, in Roztocze (PL) (May/August), W Krkonoše (CZ) (March/October), and N Šumava (CZ) (August/October). This partly overlaps with indications for dry conditions in two regions (W Krkonoše, N Šumava). Dry conditions are also indicated at Roztocze (PL) (November/April). The Swiss regions yielded hardly any significant results, probably because the pollen type is taxonomically heterogeneous and also because the pollensource populations generally occur far away, at a range of altitudes with a different local climate.

\section{Abies (PL, CZ)}

In Grindelwald $(\mathrm{CH})$ van der Knaap and van Leeuwen (2003) found a positive relationship between Abies pollen productivity and both cool weather during April/September and wet spring weather in a high-resolution pollen diagram covering the 20th century. When we compare this with the results from pollen traps, it should be kept in mind that impacts of weather in the year of pollen release and the year prior to it can not be distinguished in the pollen-diagram results.

The results agree reasonably well, as follows. In Roztocze (PL), the cool summer weather suggested by the pollen diagram is matched by the indication of cool, but also dry, May/August weather in the year prior to pollentrap collection. In N Šumava (CZ), the cool January/June indicated for the year of pollen-trap collection partly overlaps with the cool summer weather of the pollen diagram. The wet spring weather indicated by the pollen diagram is matched in $\mathrm{W}$ Krkonoše $(\mathrm{CZ})$ for the year prior to pollen-trap collection, and in $\mathrm{N}$ Šmava for the year of pollen-trap collection. We have no pollen-trap results for Abies from Switzerland because Abies pollen is so scarce in the traps.

\section{Pinus cembra $(\mathrm{CH})$}

The cool autumn and wet autumn and winter weather suggested for Pinus cembra in Grindelwald is counterintuitive as this region is the wettest and coolest in the 
Table 3 Pollen-trap data used

\begin{tabular}{|c|c|c|c|c|c|c|c|c|c|c|c|c|c|c|c|}
\hline 苟 & ๙ू ڤ̆ & $\stackrel{2}{2}$ & ڤั & $\hat{\circ}$ & த & ¿ & & & 8 & $\widetilde{N}$ & \&్ & ষ্ণ & ¿̊ & ह̊ & i̊ \\
\hline \multicolumn{16}{|c|}{ Poland: Roztocze } \\
\hline G02 & & & & & & $X$ & X & & & $X$ & $X$ & $X$ & $X$ & $\mathrm{X}$ & $\mathrm{X}$ \\
\hline G03 & & & & & $X$ & X & X & & K & X & $X$ & $X$ & $X$ & $X$ & $X$ \\
\hline G04 & & & & & $X$ & X & $X$ & & K & X & $X$ & $X$ & & $X$ & $X$ \\
\hline G05 & & & & & & X & $X$ & & K & $X$ & $X$ & $X$ & $X$ & $X$ & $X$ \\
\hline G06 & & & & & $X$ & $\mathrm{X}$ & & & & $X$ & $X$ & $X$ & $X$ & $X$ & $X$ \\
\hline
\end{tabular}

Czech Republic: Krkonoše East

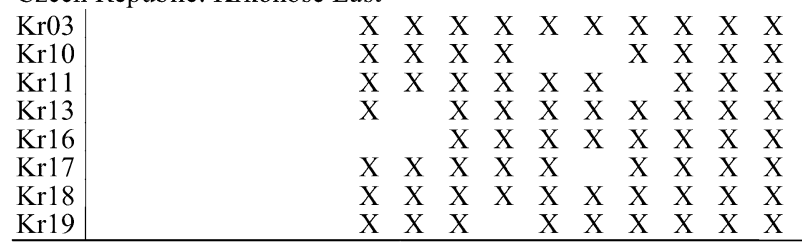

Czech Republic: Krkonoše West

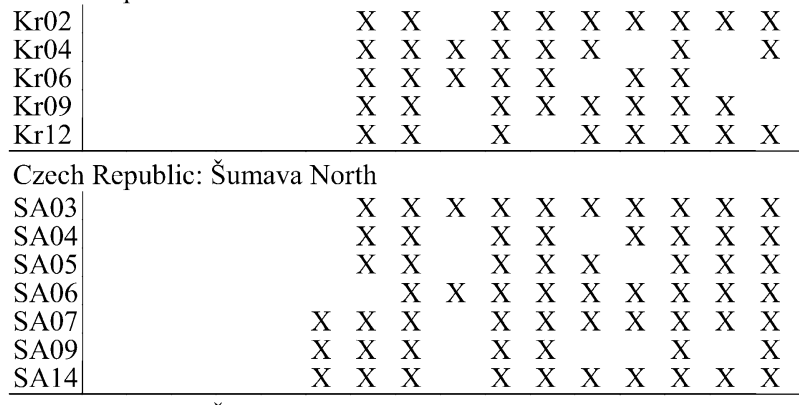

Czech Republic: Šmava South

\begin{tabular}{lllllllllllll} 
SA01 & X & & X & & X & & & & & X & X \\
SA02 & & X & X & X & X & X & X & X & X & X & X \\
SA10 & & X & X & X & X & X & X & X & X & X & X & X \\
SA15 & & X & X & & X & X & X & X & & X & X \\
SA16 & & X & X & & & X & X & X & & X & X & X \\
SA17 & & X & & X & X & & X & X & X & \\
SA18 & & & X & X & & X & X & X & & X & X & X \\
\hline Georgia: Lagodekhi & & & & & & & & & & & \\
T01 & X & X & X & X & X & X & X & X & X & X & X \\
T02 & X & X & X & & X & & X & X & X & X & X \\
T04 & X & X & X & X & & X & X & X & X & X & X \\
T06 & X & X & X & X & X & X & X & & X & & X \\
T07 & X & X & X & X & & X & X & X & X & X & X \\
T08 & X & X & & X & & X & X & X & X & X & X \\
\hline
\end{tabular}

Switzerland: Grindelwald

\begin{tabular}{l|llllllllllll} 
G06 & X & & $X$ & $X$ & $X$ & $X$ & $X$ & $X$ & $X$ & $X$ & $X$ & $X$ \\
G08 & $X$ & $X$ & & & & $X$ & $X$ & $X$ & $X$ & $X$ & $X$ & $X$ \\
G10 & $X$ & $X$ & $X$ & $X$ & $X$ & $X$ & $X$ & & $X$ & $X$ & $X$ & $X$ \\
HAG & & $X$ & $X$ & $X$ & $X$ & $X$ & $X$ & $X$ & $X$ & $X$ & $X$ & $X$ \\
\hline
\end{tabular}

Switzerland: Aletsch

$\begin{array}{lllllllllllllllll}\text { A1 } & X & X & X & X & X & X & X & X & X & X & X & X & X & X & X & X\end{array}$

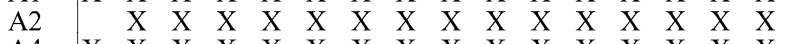
\begin{tabular}{llllllllllllllllllllll}
$\mathrm{A} 4$ & $\mathrm{X}$ & $\mathrm{X}$ & $\mathrm{X}$ & $\mathrm{X}$ & $\mathrm{X}$ & $\mathrm{X}$ & $\mathrm{X}$ & $\mathrm{X}$ & $\mathrm{X}$ & $\mathrm{X}$ & $\mathrm{X}$ & $\mathrm{X}$ & $\mathrm{X}$ & $\mathrm{X}$ & $\mathrm{X}$ & $\mathrm{X}$ \\
\hline
\end{tabular}

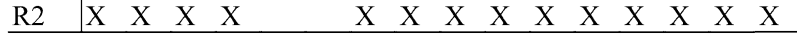
Switzerland: Simplon

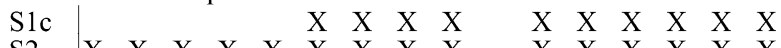
$\begin{array}{lllllllllllllllll}\mathrm{S} 2 & \mathrm{X} & \mathrm{X} & \mathrm{X} & \mathrm{X} & \mathrm{X} & \mathrm{X} & \mathrm{X} & \mathrm{X} & \mathrm{X} & & \mathrm{X} & \mathrm{X} & \mathrm{X} & \mathrm{X} & \mathrm{X} & \mathrm{X}\end{array}$ $\begin{array}{llllllllllllllll}\mathrm{S} 3 & \mathrm{X} & \mathrm{X} & \mathrm{X} & \mathrm{X} & \mathrm{X} & \mathrm{X} & \mathrm{X} & \mathrm{X} & \mathrm{X} & \mathrm{X} & \mathrm{X} & \mathrm{X} & \mathrm{X} & \mathrm{X} & \mathrm{X}\end{array}$ $\begin{array}{lllllllllllllllll}\mathrm{S} 4 & \mathrm{X} & \mathrm{X} & \mathrm{X} & \mathrm{X} & \mathrm{X} & & \mathrm{X} & & \mathrm{X} & \mathrm{X} & & \mathrm{X} & \mathrm{X} & & \mathrm{X} & \mathrm{X}\end{array}$

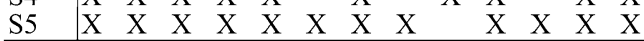

Switzerland: Zermatt ${ }^{1}$

$\begin{array}{llllllllllllllll}Z 1 & X & X & X & X & X & X & X & X & X & X & X & X & X & X & X\end{array}$

$\begin{array}{lllllllllllllllll}\mathrm{Z} 2 & \mathrm{X} & \mathrm{X} & \mathrm{X} & \mathrm{X} & \mathrm{X} & \mathrm{X} & \mathrm{X} & \mathrm{X} & \mathrm{X} & \mathrm{X} & \mathrm{X} & \mathrm{X} & \mathrm{X} & \mathrm{X} & \mathrm{X}\end{array}$

$\begin{array}{lllllllllllllllllllll}Z 3 & X & X & X & X & X & X & X & X & X & X & X & X & X & X & X\end{array}$

$\begin{array}{llllllllllllllll}Z 4 & X & X & X & X & X & X & X & X & X & X & X & X & X & X & X\end{array}$

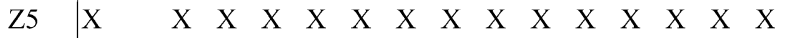

1 A.D. 1993 and 1994 are combined in the original data, their results are used for 1994
Table 4 Outliers in pollen time-series; underlined outliers are removed from the time series prior to statistical analysis

\begin{tabular}{|c|c|c|c|}
\hline \multirow{2}{*}{$\begin{array}{l}\text { Country - } \\
\text { Region }\end{array}$} & \multirow[t]{2}{*}{ Pollen type } & \multicolumn{2}{|l|}{ Outlier years: } \\
\hline & & $\begin{array}{l}\text { in complete } \\
\text { time-series }\end{array}$ & $\begin{array}{l}\text { one outlier } \\
\text { removed }^{2}\end{array}$ \\
\hline \multirow[t]{2}{*}{ PL-ROZ } & Betula & 2002 & - \\
\hline & Picea & 2002,2005 & - \\
\hline \multirow[t]{2}{*}{ CZ-KRE } & Fagus & $\underline{2004} !^{1}$ & - \\
\hline & Quercus & 2004 & - \\
\hline \multirow[t]{4}{*}{$\mathrm{CZ}-\mathrm{KRW}$} & Cichorioideae & {$[2002]^{3}$} & \\
\hline & Corylus & $2005 !, 2000$ & - \\
\hline & Cyperaceae & $\frac{2005 !}{2006} !, 1998$ & - \\
\hline & Pinus & {$[1999]^{3}$} & \\
\hline \multirow[t]{9}{*}{ CZ-SUN } & Abies & 2007 & 2002 \\
\hline & Betula & 2000 & 2003 \\
\hline & Cyperaceae & {$[\underline{2002}]^{3}$} & \\
\hline & Gramineae & 2001 & - \\
\hline & Monolete fern spores & 2003 & 2001 \\
\hline & Picea & {$[2003]^{3}$} & 2000 \\
\hline & Pinus & {$[\underline{2001}]^{3}$} & - \\
\hline & Quercus & $\underline{2001}$ & - \\
\hline & Salix & 2001 & - \\
\hline \multirow[t]{7}{*}{ CZ-SUS } & Alnus & $\underline{2000}$ & - \\
\hline & Betula & $\underline{2000} !$ & - \\
\hline & Fagus & 2000 & - \\
\hline & Gramineae & $\underline{2001}$ & - \\
\hline & Monolete fern spores & $\underline{2001}$ & - \\
\hline & Picea & {$[\underline{2003}]^{3}$} & - \\
\hline & Salix & $\underline{2001}$ & - \\
\hline \multirow[t]{2}{*}{$\mathrm{CH}-\mathrm{GRI}$} & Cichorioideae & $\underline{2003}$ & - \\
\hline & Potentilla-type & $\underline{2003}$ & - \\
\hline \multirow[t]{2}{*}{ CH-ALE } & Betula & $\underline{1992}$ & - \\
\hline & Ranunculus & 1997 & - \\
\hline CH-SIM & Monolete fern spores & 2001 & $-[1992]^{3}$ \\
\hline \multirow[t]{3}{*}{$\mathrm{CH}-\mathrm{ZER}$} & Betula & 1997 & - \\
\hline & Cichorioideae & $\underline{2005}$ & - \\
\hline & Gramineae & $\frac{2003 !}{2007} !, 2002$ & $\begin{array}{l}1999,2000, \\
2002,2007\end{array}$ \\
\hline \multirow[t]{4}{*}{ GE-LAG } & Alnus & $2000 !$ & - \\
\hline & Juglans & $\underline{\underline{2006}}$ & - \\
\hline & $\begin{array}{l}\text { Ostrya carpinifolial } \\
\text { Carpinus orientalis }\end{array}$ & $\overline{2000}, 2004$ & $2004 !$ \\
\hline & Pterocarya & 2001 & - \\
\hline
\end{tabular}

1 Strong outliers have exclamation mark

${ }^{2}$ In case of several outliers in the complete time series, the first listed was removed. Underlined question mark (?) indicates that outlier removal is tested (CZ-SUS Picea 2003; CH-SIM Monolete fern spores both 2001 and 1992)

${ }^{3}$ [In square brackets: Visually determined outlier in normal probability plot, not statistically confirmed]

Swiss Alps and this tree is characteristic of the (sub-) continental (dry) central Alpine regions of Aletsch and Zermatt. The indication of wetness is even stronger for 
Aletsch (June/April). Simplon and Zermatt did not yield results of importance.

Van der Knaap and van Leeuwen (2003) obtained only weak Pinus cembra/climate relationships (no strong significance) on the basis of pollen diagrams from Grindelwald and Aletsch. A wet summer correlation at Aletsch is the only agreement with the pollen-trap results; no precipitation signal was found for Grindelwald. The pollen diagram for Grindelwald suggested a warm August/September, and at Aletsch it suggested a warm June/July. This was not found in the pollen-trap results. Taken together, the results support the conclusion, proposed by van der Knaap and van Leeuwen (2003), that the rather poorly defined pollen/climate relationships may indicate that climatic stress plays a small role in the production of Pinus cembra pollen at this elevation, several hundred metres below the climatic upper limit.

\section{$\operatorname{Larix}(\mathrm{CH})$}

The pollen-trap results for Larix are consistent among the three Swiss regions where the tree is abundant. They are also consistent with the results of the high-resolution pollen diagram for Aletsch, presented by van der Knaap and van Leeuwen (2003), as follows. The pollen-trap results indicate that a warm March/July in Aletsch and Simplon favours Larix PAR in the next year, as does a warm March in Zermatt, though $P$-values are not very low. This makes sense for a tree forming the forest limit (together with Pinus cembra). The result from the pollen diagram for Aletsch is comparable: a warm April/September favouring Larix pollen. In all three pollen-trapping regions a wet (snow rich) winter favours high Larix PAR, though again with some quite high $P$-values. For Aletsch February/May yields the most significant result, which overlaps and thus agrees with the wet April/June found on the basis of the pollen diagram.

\section{Juniperus (CH)}

The results for Juniperus differ markedly among the regions. In Grindelwald a dry autumn to mid-winter (October/January) favours high Juniperus PAR. In Aletsch wet conditions for most of the time (June/May, with an interruption) have the same effect. We have insufficient background information to judge whether this makes sense in relation to the ecological conditions in the two regions. Simplon and Zermatt do not yield results of import.

\section{Fagus (PL, CZ, GE)}

Summer warmth is found to favour Fagus PAR in the next year in Roztocze (PL; July), E Krkonoše (CZ; May/July), and at lower statistical significance, in W Krkonoše (May/ October) and Lagodekhi (GE; July/October). This makes sense in these mountain areas, where beech grows at a relatively high elevation. Results for precipitation were only obtained in regions where temperature yielded nothing of import, and vice versa: a dry winter favours high Fagus PAR both in N Šumava (CZ; December/February) and S Šumava (November/March, however with lower significance). This may indicate that too much snow harms the trees in these regions. In addition, a wet May/August in N Šumava favours Fagus PAR.

\section{Quercus (PL, CZ, GE)}

In N Šumava (CZ), a warm autumn and winter (September/ February) was found to favour high Quercus PAR. This result is not matched in any other region. Results for precipitation, on the other hand, show good agreement in the Czech regions: a wet late winter, spring and summer are found to favour high Quercus PAR in the next year in both E and W Krkonoše and in N Šumava. Quercus is a thermophilous tree and is therefore uncommon in these moist, cool Czech mountain regions, so most of the pollen must have been transported from forest stands in distant areas, at lower elevation, where the climate is drier and may cause drought stress. Van der Knaap and van Leeuwen (2003) found that a cool April/September favours Quercus pollen productivity, based on a pollen diagram from Grindelwald $(\mathrm{CH})$. This result contrasts with the wet conditions found on the basis of pollen traps, and also the region lies in a different mountain area, but the two results point in the same direction of heat or drought stress on Quercus trees.

\section{Betula (PL, CZ, CH)}

Results for Betula show agreement among regions only in the requirement of a dry winter (2-4 months in November/ February) in Roztocze (PL), both E and W Krkonoše (CZ) and with less strong significance $\mathrm{N}$ Šumava (CZ), and Zermatt $(\mathrm{CH})$. This agrees with the common field observation that birches especially suffer from heavy snow and glazed frost.

\section{Corylus (CZ, GE)}

The results for Corylus differ among the regions. Those for $\mathrm{N}$ Šumava (CZ) are partly counter-intuitive. First, the correlation of a cold January/March with a high Corylus PAR one year later seems far-fetched. Second, the correlation of a cold June/July with a high Corylus PAR in the same year is strange as these months fall after the period in which the pollen was released. In E Krkonoše (CZ), February/July wetness correlates with a high Corylus PAR one 
year later; this correlation is repeated in N Šumava (CZ) for May only. Three other regions yield no or very few significant correlations.

\section{Alnus glutinosa-type (PL, CZ, GE)}

Results for temperature are limited. Low July/August temperatures result in high Alnus glutinosa-type PAR in the next year in E Krkonoše (CZ), and also in N Šumava (CZ) but with a weaker correlation. Precipitation produces more interesting results. One result is rather similar to one for Corylus: in E Krkonoše (CZ), January/June wetness correlates with a high Alnus glutinosa-type PAR in the next year, and this correlation is repeated in a weak form in $\mathrm{N}$ Šumava (CZ). A result for W Krkonoše (CZ) that is rather similar to one result for Betula, is that a dry August/January is followed by a high Alnus glutinosa-type PAR. Dryness is also indicated in Roztocze (PL) for November/ May. Both W and E Krkonoše (CZ) yield the correlation of spring and summer wetness with high Alnus glutinosa-type PAR in the same year; however for E Krkonoše this extends beyond the period of pollen release. To summarize, the effect of weather conditions on Alnus glutinosa-type pollen productivity seems to be governed by precipitation rather than by temperature; the differences of responses among the regions may be related to differences in the habitat of the source tree populations.

\section{Alnus viridis $(\mathrm{CH})$}

The results for all the four Swiss Alpine regions agree in the positive effects of a cool autumn on Alnus viridis PAR. The relevant sequence of months differs among the regions but it includes November in all cases. In Aletsch, warm conditions are indicated for the year of pollen-trap collection, extending even into the months after the release of the pollen. A clear precipitation signal is only found in the driest region, Zermatt. Where this signal is stronger than the temperature signal which it overlaps in months, wet summer and autumn weather is suggested as favouring Alnus viridis PAR in the next year. In general Alnus viridis pollen productivity seems to be favoured by cool and not too dry summers and especially autumns.

\section{$\operatorname{Salix}(\mathrm{CZ}, \mathrm{CH})$}

The results for Salix include series of months that produce strong correlations of climate with pollen in all studied regions. This suggests that the pollen productivity of Salix has a strong climatic forcing everywhere. There is, however, hardly any overlap in the relevant months among the different regions, either for temperature or for precipitation. The different timings of climatic impacts among regions may imply that the local habitat conditions of the pollen-source populations are different in each region. One reason for this may be that the regions harbour different sets of Salix species, and different species differ in their habitat requirements. High temperatures favour high Salix PAR in all cases except one, and wet conditions in all cases except two in one single region, even though the relevant month series show little overlap. This indicates that warmth and wetness stimulate Salix pollen productivity. This agrees well with the general ecology of Salix (preference of wet conditions) and the high elevation of the regions (warmth limitation) (Ellenberg 1996).

\section{Results for Lagodekhi (GE)}

It is convenient to discuss all the Georgian pollen types here, separately from the other regions, since comparisons with other regions must remain limited, due to differences in plant taxonomy and climate, as well as the lack of precipitation data for this region. Warm conditions were found to have positive effects on the next year PAR of Alnus, Fagus, Quercus, Acer, Juglans, Pterocarya and Chenopodiaceae, warm conditions on the same year PAR of Artemisia, and cool conditions, especially in autumn and winter, on the PAR of Tilia and Castanea. No significant results were obtained for Ostrya carpinifolia/Carpinus orientalis, Corylus, Pinus and Hedera.

Herbs

When considering the impact of weather on pollen production in the following year by herbs, we should think in terms of impacts on general plant fitness and growth. Herb $\mathrm{PAR} /$ climate relations in the year prior to pollen-trap collection are thought, therefore, to be related to the performance of the plants in general.

For Gramineae (grasses), the general pattern observable in pollen/climate relationships is that cool and moist spring and summer weather favours high PAR in the next year. One exception occurs, in Aletsch $(\mathrm{CH})$, where the indication of warm spring weather is the opposite. The only indication for dryness in the results for grasses is winter dryness in N Šumava (CZ). Weather of the current year was only found to influence Gramineae PAR in one case (E Krkonoše, CZ).

The results for Cyperaceae have only few cases of highly significant pollen/climate correlation, and most of these are in the year prior to pollen release. Variation in weather conditions has apparently little impact on flowering.

Cases of highly significant Ranunculus pollen/climate correlations were found in all regions where the pollen type was investigated, but in different months and/or with 
different correlation signs. Superficial similarities in results occur in three pairs of regions, but only one pair involves regions that lie next to each other, so these similarities might be due to chance.

For monolete fern spores, Cichorioideae, and Potentillatype, a moderate number of clear spore or pollen/climate relationships were found, which, however, differ among the regions. These cases occur as often in the year prior to pollen-trap collection as in the year of pollen-trap collection. Plantago lanceolata pollen was studied only in Roztocze (PL), and no climate/pollen relationships of import were found.

\section{Discussion}

General considerations

Much of the variation in pollen-trap PAR is not related to climate. The noisiness of the relationship between pollen and climate can be, in part, attributed to the relevance of the climate parameters available to the pollen-source areas. Measured climate is more applicable to pollen-source areas when the climate at the measuring station corresponds closely to the climate of the pollen-trap region and when the region has a uniform climate. Precipitation patterns can vary considerably over short distances, whereas trends in temperature are usually more coherent in space. This is exemplified in Fig. 3 by the broad variation in precipitation curves compared to the strong similarity of the temperature curves. Therefore, it is inevitable that the pollen-source areas are more closely related to trends in measured temperature than the trends in measured precipitation. As a result, the statistical pollen/climate relationships we have obtained are likely to be more robust for temperature than for precipitation.

Data noisiness can have two different effects on the pollen/climate correlations. On the one hand, it may reduce the strength of the correlation so that important temperature or precipitation forcings of pollen-trap PAR are missed. On the other hand, it may increase the strength of some correlations by chance, so that some statistically significant pollen/climate correlations shown in Fig. 4 might be spurious. Our impression was that results for single-month parameters are particularly prone to being spurious, so we tended to ignore those that were not associated with significant results of multi-month climate parameters.

One of the factors that determine the pollen/climate relationships recorded in pollen traps is the choice of the location of pollen traps in the field, because there are good reasons why the same taxon could behave differently in different places. Climatic stress on a taxon varies over its distribution range, and the climate/pollen relationship recorded in a pollen trap depends on the position of the trap in relation to the climate envelope of the taxon being studied. We would therefore predict that pollen traps placed in European lowland regions would yield quite different and possibly contradictory results for the same pollen types compared to traps in mountains.

This effect is aggravated by the observation that the actual distribution of many taxa, especially trees, has been modified by human action. Forestry activities, for example, have modified the distribution of many tree species. Local studies would therefore be needed to unravel many of the pollen/climate relationships emerging from pollen-trap studies. A recognized limitation of this study is therefore that vegetation and environmental data were used in only the most general way. More detailed analysis would involve so much effort that it can only be done for individual pollen-trap regions or groups of regions.

Trees and shrubs

Among the six conifer taxa studied, four yielded pollen/ climate relationships that showed similarities among the regions. These relationships made sense ecologically and were, in general terms, similar to earlier findings reported in the literature (mainly van der Knaap and van Leeuwen 2003; Huusko and Hicks 2009). This includes summer warmth for Picea and Pinus non-cembra and spring warmth for Larix favouring pollen productivity in the next year, and cool summers favouring pollen productivity in Abies. For one conifer (Pinus cembra), the lack of clear pollen/climate relationships was similar to an earlier finding reported in the literature.

Van der Knaap and van Leeuwen (2003, p. 823) tentatively explained the results for Abies in Grindelwald (cool April/September and wet spring favouring pollen) by speculating that 'it may be that populations of Abies responsible for the pollen signal grow at their lower altitudinal limit, where they experience drought stress in spring and heat stress in summer'. This speculation was motivated by the observation that the present-day Abies pollen-source populations for Grindelwald grow mostly in the hills just north of the Alps where forestry favours the taxon, whereas in the prehistoric past Abies had an enormous altitudinal range in the northern Alps (pollen data in Welten 1982; van der Knaap and Ammann 1997; van der Knaap et al. 2000, 2001b), reaching up to the forest limit (Wick et al. 2003), but declined and contracted since Neolithic times. Similar Abies declines were found in the Czech mountains Šumava (Svobodová et al. 2001, 2002) and Krkonoše (Svobodová 2004). In the southern Alps, on the other hand, the Abies decline since Neolithic times took place not only at high elevations but also at low elevations to an even greater extent (Tinner et al. 1999; Tinner and 
Ammann 2005). These and other studies stimulated Tinner and Lotter (2006) to propose that drought is limiting Abies in its distribution far more than temperature.

Different regions produced similar results for a number of broadleaved (deciduous) trees. Fagus produced a similar result to Picea, for example, namely that summer warmth leads to high PAR in the next year, which makes sense for a tree growing in mountains. Wet conditions were found to stimulate Quercus PAR in the next year, which has some support in the literature. Betula PAR was found to be enhanced by dry winters, Alnus viridis PAR by cool and not too dry summer-autumn, and Salix PAR by warmth and wetness in different seasons. For Alnus glutinosa-type, precipitation seemed more important for pollen than temperature, although the effect differed among the regions. The results for Corylus differed strongly between the regions and we failed to interpret them.

The similarities in results among regions described above support the validity of such results. This is especially true when they seem to make sense ecologically. When the same type of relationships were reported earlier for the same taxa this lends further support. Absence of such similarities, or our inability to link statistically significant correlations to ecological properties of plant taxa, are, however, not proof that they are not valid, as this may be related to differences in local habitat conditions of the plant populations of which we still do not possess sufficient information.

\section{Results for Lagodekhi (GE)}

Precipitation data were not available for Georgia, so we can only speculate on the relative importance of moisture for any pollen type. If we accept that the temperature relationships found are meaningful, we may suppose that the pollen-source populations of the relevant taxa grow in different positions in relation to their temperature-dependent altitudinal range: those with positive warmth effects closer to the upper altitudinal limit and those with negative warmth effects closer to the lower limit.

\section{Herbs and Salix}

Four pollen/spore types of herbs (Ranunculus, Monolete fern spores, Cichorioideae and Potentilla-type) yielded rather sporadic correlations with low $P$-values. Clear geographical patterns could not be discovered. This scarcity and heterogeneity of results may be, in part, due to the taxonomic heterogeneity of the pollen (spore) types, and to the diversity of the habitats in which the pollen-source populations are growing. Plantago lanceolata pollen, on the other hand, involves a single species only in the region where it was studied (Roztocze PL). Nevertheless it yielded hardly any results, which may mean that its pollen productivity is not under climatic stress.

Gramineae pollen was the only herb that produced similar results among the different regions. Cool and wet spring and summer weather favoured PAR in the next year. The occurrence of such a general trend is amazing, because Gramineae is both taxonomically and ecologically heterogeneous, like the four other herb pollen or spore types in this study for which no general trend could be discovered. Salix is another case of a taxonomically heterogeneous pollen type that, nevertheless, yielded a general trend in the pollen/climate relationships (warm and wet weather favouring the PAR for both the current and the following year).

Unexpectedly, weather conditions were not found to influence Gramineae PAR in the same year, and Cyperaceae also exhibits this tendency. The effect of weather conditions on pollen productivity of these two taxa has a delay of one year, which suggests that the flowering abundance of the plants depends on their general, partly weather-dependent, fitness before the onset of flowering. No bias of results to one of the two years can be observed in the other herb pollen types.

\section{Concluding remarks}

Our pollen-trap time-series are unique in being so long: 10 or more years is a considerable time span for field-based studies carried out in a consistent way in different countries and with very little or (mostly) no funding (Giesecke et al. 2010). This became possible thanks to the scientific inspiration and support of Sheila Hicks (Oulu, Finland) who started the whole business and then by the motivation of the scientists involved. She also suggested a type of pollen trap simple enough to be used in most countries (Hicks and Hyvärinen 1986).

Nevertheless, in the present pollen/climate explorations we frequently found the time-series to be too short: 10-16 data points of observation are, after all, not much in a complex natural system. A clear expression of this is the occurrence of single data points that fall far outside the range of the majority of values (outliers). If extremes are repeated, this forms a pattern which can be important for allergology, for example the recurrent pollen extremes observed for Betula (Emberlin et al. 1993; Hicks et al. 1994; Spieksma et al. 1995; Corden et al. 2000; Latałowa et al. 2002; Ranta et al. 2008b) and Quercus (Spieksma et al. 2003). It is easy to understand that pollen productivity responds differently to climate extremes rather than to regular variations. For example, a tree that produces more pollen when it receives more warmth in summer may fail to do so when the weather is unseasonably hot, which causes an outlier in the PAR/ climate relationship. Another possibility is that a climate 
factor influences PAR only when it exceeds a certain threshold. Extremes will occur more frequently in longer time-series and thus they cease to be outliers. Therefore some of the results will change if we repeat the analysis in the future using much longer time-series.

The longer the time-series is, the better we can apply the results to our pollen diagrams. Nevertheless, care should be taken when using pollen-trap PAR for interpretation of pollen diagrams. Pollen accumulation rates are very difficult to estimate reliably for sedimentary sequences, since it demands a near-perfect chronological control, which is only approached in annually laminated sediments (Lotter 1999). In addition, it requires a detailed understanding of the taphonomic processes in the study basin, to account for sediment focussing, water-transport of pollen, re-deposition and loss. In practice, PAR tends to be much noisier than percentage values, and thus more difficult to interpret (Moore et al. 1991).

Recent comparisons of dynamic modelling outputs with sedimentary pollen and macrofossil records suggest that plant-population dynamics are much more important than productivity changes at decadal to centennial time scales (Heiri et al. 2006). Our pollen-trap results, however, relate to weather-dependent pollen-productivity fluctuations, not to plant-population dynamics. This implies that the application of these pollen/climate relationships to sedimentary pollen records requires near-annual resolution and should be restricted to sub-decadal plant or vegetation dynamics; examples are the studies by van der Knaap and van Leeuwen (2003) and Kamenik et al. (2009). Our present results do provide valuable hints, but we recommend caution in their application. Furthermore we recommend that the PMP pollen-trapping work should be continued in order to produce much longer time-series than are available today, until we can pass it onto the next generation of researchers.

\footnotetext{
Acknowledgements We dedicate this paper in gratitude to the 'mother of PMP' Sheila Hicks (Oulu, Finland). Field assistance was given by Han van Dobben (NL; traps in $\mathrm{CH}$ ), Josef Harčarik (CZ; Administratory of the Krkonoše National Park), and Shota Eriashvili (Georgia). Simon Connor (AU/P) made constructive comments on an earlier version of the manuscript. We thank John Birks and an anonymous reviewer for constructive remarks. Chris Meechan (UK) assisted in the production of Fig. 1. Permission to work in National Parks was obtained through Zdenka Křenová (CZ; Administratory of the Šumava National Park and Reserve). Laboratory assistance was given by Irena Krtilová (CZ), Tamuna Khakhutashvili, and Tamara Mchedlidze (Georgia). Climate data were shared by MeteoSchweiz (CH). Dana Pýchová (Czech Hydrometeorological Institute, Prague) verified climate data. Pollen monitoring was financially supported by the Polish Ministry of Science and Higher Education (research project N304 092 32/3590; AD 2007-2010) (PL), the Czech Academy of Sciences AV0Z60050516, and for the last years the Grant Agency of the Academy of Sciences of the Czech Republic (IAAX00130801, IAAX00050801). This research is part of the Pollen Monitoring Programme PMP (INQUA working group; http://pmp.oulu.fi/) and
}

contributes to the European Union project Millennium-European climate of the last millennium (SUSTDEV-2004-3.1.4.1).

Open Access This article is distributed under the terms of the Creative Commons Attribution Noncommercial License which permits any noncommercial use, distribution, and reproduction in any medium, provided the original author(s) and source are credited.

\section{References}

Agrometeorological Rapporteur (1996-2008) Agrometeorologický zpravodaj. Český hydrometeorologický ústav, Úsek meteorologie a klimatologie (Czech Hydrometeorological Institute, Department of Meteorology and Climatology), Praha. Volumes 16-28 (in Czech)

Autio J, Hicks S (2004) Annual variations in meteorological conditions and pollen deposition on the fell Aakenustunturi in northern Finland. Potential for using fossil pollen as a climate proxy. Grana 43:31-47

Barnekow L, Loader NJ, Hicks S, Froyd CA, Goslar T (2007) Strong correlation between summer temperature and pollen accumulation rates for Pinus sylvestris, Picea abies and Betula spp. in a highresolution record from northern Sweden. J Quat Sci 22:653-658

Bennett KD, Hicks S (2005) Numerical analysis of surface and fossil pollen spectra from northern Fennoscandia. J Biogeogr 32: 407-423

Birks HH, Bjune AE (2010) Can we detect a west-Norwegian treeline from modern samples of plant remains and pollen? Results from the DOORMAT project. Veget Hist Archaeobot 19 (this volume)

Corden J, Millington W, Bailey J, Brookes M, Caulton E, Emberlin J, Mullins J, Simpson C, Wood A (2000) UK regional variations in Betula pollen (1993-1997). Aerobiologia 16:227-232

Ellenberg H (1996) Vegetation Mitteleuropas mit den Alpen in ökologischer Sicht, 5th edn. Ulmer, Stuttgart

Emberlin J, Savage M, Woodman R (1993) Annual variation in Betula pollen seasons in London 1961-1990. Grana 32:359-363

Filipova-Marinova MV, Kvavadze EV, Connor SE, Sjögren P (2010) Estimating absolute pollen productivity for some European Tertiary-relict taxa. Veget Hist Archaeobot 19 (this volume)

Gerasimidis A, Panajiotidis S, Hicks S, Athanasiadis N (2006) An eight-year record of pollen deposition in the Pieria mountains (N. Greece) and its significance for interpreting fossil pollen assemblages. Rev Palaeobot Palynol 141:231-243

Giesecke T, Bjune AE, Chiverrell RC, Seppä H, Ojala AEK, Birks HJB (2008) Exploring Holocene continentality changes in Fennoscandia using present and past tree distributions. Quat Sci Rev 27:1,296-1308

Giesecke T, Fontana SL, van der Knaap WO, Pardoe HS, Pidek IA (2010) From early pollen trapping experiments to the Pollen Monitoring Programme. Veget Hist Archaeobot 19 (this volume)

Goslar T, van der Knaap WO, Kamenik C, van Leeuwen JFN (2009) Free-shape ${ }^{14} \mathrm{C}$ age-depth modelling of an intensively dated modern peat profile. J Quat Sci 24:481-499

Hammer $\varnothing$, Harper DAT, Ryan PD (2009) PAST: Paleontological Statistics software package for education and data analysis. Palaeontologia Electronica 4(1):9 pp. http://folk.uio.no/ohammer/ past

Heikkilä M, Seppä H (2003) A 11,000 yr palaeotemperature reconstruction from the southern boreal zone in Finland. Quat Sci Rev 22:541-554

Heiri C, Bugmann H, Tinner W, Heiri O, Lischke H (2006) A modelbased reconstruction of Holocene treeline dynamics in the Central Swiss Alps. J Ecol 94:206-216 
Hicks S (1974) A method of using modern pollen rain values to provide a time-scale for pollen diagrams from peat deposits. Mem Soc Fauna Flora Fennica 49:21-33

Hicks S (1977) Modern pollen rain in Finnish Lapland investigated by analysis of surface moss samples. New Phytol 78:715-734

Hicks S (1985) Modern pollen deposition records from Kuusamo, Finland. I. Seasonal and annual variation. Grana 24:167-184

Hicks S (2001) The use of annual arboreal pollen deposition values for delimiting tree-lines in the landscape and exploring models of pollen dispersal. Rev Palaeobot Palynol 117:1-29

Hicks S (2006) When no pollen does not mean no trees. Veget Hist Archaeobot 15:253-261

Hicks S, Hyvärinen V-P (1986) Sampling modern pollen deposition by means of "Tauber traps": some considerations. Pollen Spores 28:219-242

Hicks S, Sunnari A (2005) Adding precision to the spatial factor of vegetation reconstructed from pollen assemblages. Plant Biosystems 139:127-134

Hicks S, Helander M, Heino S (1994) Birch pollen production, transport and deposition for the period 1984-1993 at Kevo, northernmost Finland. Aerobiologia 10:183-191

Hicks S, Ammann B, Latałowa M, Pardoe H, Tinsley H (1996) European Pollen Monitoring Programme: Project Description and Guidelines. Oulu Univ Press, Oulu

Hicks S, Tinsley H, Pardoe H, Cundill P (1999) European Pollen Monitoring Programme: Supplement to the Guidelines. Oulu Univ Press, Oulu

Hicks S, Tinsley H, Huusko A, Jensen C, Hattestrand M, Gerasimides A, Kvavadze E (2001) Some comments on spatial variation in arboreal pollen deposition: first records from the Pollen Monitoring Programme (PMP). Rev Palaeobot Palynol 117:183-194

Hicks S, Goslar T, van der Borg K (2004) A near annual record of recent tree-line dynamics from northern Finland. Acta Palaeobot 44:299-316

Huusko A, Hicks S (2009) Conifer pollen abundance provides a proxy for summer temperature: evidence from the latitudinal forest limit in Finland. J Quat Sci 24:522-528

Jensen C, Vorren K-D, Mørkved B (2007) Annual pollen accumulation rate (PAR) at the boreal and alpine forest-line of northwestern Norway, with special emphasis on Pinus sylvestris and Betula pubescens. Rev Palaeobot Palynol 144:337-361

Kamenik C, van der Knaap WO, van Leeuwen JFN, Goslar T (2009) Pollen/climate calibration based on a near-annual peat sequence from the Swiss Alps. J Quat Sci 24:529-546

Körner C (1999) Alpine plant life. Springer, Berlin

Kvavadze E (2001) Annual modern pollen deposition in the foothills of the Lagodekhi Reservation (Caucasus, East Georgia), related to vegetation and climate. Acta Palaeobot 41:355-364

Latałowa M, Miętus M, Uruska A (2002) Seasonal variation in the atmospheric Betula pollen count in Gdańsk (southern Baltic coast) in relation to meteorological parameters. Aerobiologia $18: 33-43$

Levetin E, Rogers C, Hall S (2000) Comparison of pollen sampling with a Burkard Spore Trap and Tauber Trap in a warm temperate climate. Grana 39:294-302

Lotter AF (1999) Late-glacial and Holocene vegetation history and dynamics as evidenced by pollen and plant macrofossil analyses in annually laminated sediments from Soppensee (Central Switzerland). Veget Hist Archaeobot 8:165-184

Menzel A (2003) Plant phenological anomalies in Germany and their relation to air temperature and NAO. Clim Change 57:243-263

Moore PD, Webb JA, Collinson ME (1991) Pollen analysis, 2nd edn. Blackwell, London

Nielsen AB, Møller PF, Giesecke T, Stavngaard B, Fontana SL, Bradshaw RHW (2010) Inter-annual flowering variability monitored by pollen traps below the canopy in Draved forest, Denmark. Veget Hist Archaeobot 19 (this volume)

Oikonen MK, Hicks S, Heino S, Rantio-Lehtimäki A (2005) The start of the birch pollen season in Finnish Lapland: separating nonlocal from local birch pollen and the implication for allergy sufferers. Grana 44:81-186

Pardoe HS, Giesecke T, van der Knaap WO, Svitavská-Svobodová H, Kvavadze EV, Panajiotidis S, Gerasimidis A, Pidek IA, Zimny M, Święta-Musznicka J, Latałowa M, Noryskiewicz AM, Bozilova E, Tonkov S, Filipova-Marinova MV, van Leeuwen JFN, Kalnina L (2010) Comparing pollen spectra from modified Tauber traps and moss samples: examples from a selection of woodlands across Europe. Veget Hist Archaeobot 19 (this volume)

Pidek IA, Weryszko-Chmielewska E, Piotrowska K (2006) Comparison of pollen concentration of selected tree taxa in Lublin and in the Roztocze region (SE Poland) - the results of three monitoring methods. Acta Agrobot 59:355-364

Pidek IA, Svitavská-Svobodová H, van der Knaap WO, Noryśkiewicz AM, Filbrandt-Czaja A, Noryśkiewicz B, Latałowa M, Zimny M, Święta-Musznicka J, Bozilova E, Tonkov S, FilipovaMarinova M, Poska A, Giesecke T, Gikov A (2010) Variation in annual pollen accumulation rates of Fagus along a N-S transect in Europe based on pollen traps. Veget Hist Archaeobot 19 (this volume). doi:10.1007/s00334-010-0248-0

Ranta H, Satri P (2007) Synchronized inter-annual fluctuation of flowering intensity affects the exposure to allergenic tree pollen in North Europe. Grana 46:274-284

Ranta H, Oksanen A, Hokkanen T, Bondestam K, Heino S (2005) Masting by Betula-species; applying the resource bucget model to north European data sets. Int J Biometeorol 49:146-151

Ranta H, Sokol C, Hicks S (2007) Comparison of time-series measurements between a volumetric air sampler and a Tauber pollen trap in the northern tree-line area of Fennoscandia. In: Kalnina L, Luksevic E (eds) Abstracts. Pollen Monitoring Programme 6th International Meeting, 3-9 June 2007, Jurmala, Latvia, pp 73-74

Ranta H, Sokol C, Hicks S, Heino S, Kubin E (2008a) How do airborne and deposition pollen samplers reflect the atmospheric dispersal of different pollen types? An example from northern Finland. Grana 47:285-296

Ranta H, Hokkanen T, Linkosalo T, Laukkanen L, Bondestam K (2008b) Male flowering of birch; Spatial synchronization, year to year variation and relation of catkin numbers and airborne pollen counts. For Ecol Manag 255:643-650

Räsänen S, Hicks S, Odgaard BV (2004) Pollen deposition in mosses and in a modified 'Tauber trap' from Hailuoto, Finland: what exactly do the mosses record? Rev Palaeobot Palynol 129: $103-116$

Rodriguez de la Cruz D, Sanchez Reyes E, Sanchez Sanchez J (2008) Aerobiological study of Fagaceae pollen in the middle-west of Spain. Aerobiologia 24:67-76

Seppä H, Birks HJB (2001) July mean temperature and annual precipitation trends during the Holocene in the Fennoscandian tree-line area: pollen-based climate reconstructions. Holocene 11:527-539

Seppä H, Birks HJB (2002) Holocene climate reconstruction from the Fennoscandian tree-line area based on pollen data from Toskaljavri. Quat Res 57:191-199

Seppä H, Hicks S (2006) Integration of modern and past pollen accumulation rate (PAR) records across the arctic tree-line: a method for more precise vegetation reconstructions. Quat Sci Rev 25:1,501-1516

Sjögren P, van der Knaap WO, Huusko A, van Leeuwen JFN (2008) Pollen productivity, dispersal, and correction factors for major 
tree taxa in the Swiss Alps based on pollen-trap results. Rev Palaeobot Palynol 152:200-210

Sjögren P, Connor SE, van der Knaap WO (2010) The development of composite pollen-dispersal functions for estimating absolute pollen productivity in the Swiss Alps. Veget Hist Archaeobot 19 (this volume)

Spieksma FTM, Emberlin JC, Hjelmroos M, Jäger S, Leuschner RM (1995) Atmospheric birch (Betula) pollen in Europe: trends and fluctuations in annual quantities and the starting dates of the season. Grana 34:51-61

Spieksma FTM, Corden JM, Detandt M, Millington WM, Nikkels H, Nolard N, Schoenmakers CHH, Wachter R, de Weger LA, Willems R, Emberlin J (2003) Quantitative trends in annual totals of five common airborne pollen types (Betula, Quercus, Poaceae, Urtica and Artemisia), at five pollen-monitoring stations in western Europe. Aerobiologia 19:171-184

Studer S, Appenzeller C, Defila C (2005) Inter-annual variability and decadal trends in Alpine Spring phenology: a multivariate analysis approach. Clim Change 73:395-414

Svobodová H (2004) Vývoj vegetace na Upském rašeliništi v holocénu. Development of the Vegetation on Upské rašeliniště Mire in the Holocene. Opera Corcontica 41:124-130

Svobodová H, Reille M, Goeury C (2001) Past vegetation dynamics of Vltavský luh, upper Vltava valley in the Šumava mountains, Czech Republic. Veget Hist Archaeobot 10:185-199

Svobodová H, Soukupová L, Reille M (2002) Diversified development of mountain mires, Bohemian Forest, Central Europe, in the last 13,000 years. Quat Int 91:123-135

Tinner W, Ammann B (2005) Long-term responses of mountain ecosystems to environmental changes: Resilience, adjustment, and vulnerability. In: Huber UM, Bugmann H, Reasoner M (eds) Global change and mountain research-state of knowledge overview. Advances in global change research. Springer, Dordrecht, pp 133-144

Tinner W, Lotter AF (2006) Holocene expansions of Fagus silvatica and Abies alba in Central Europe: where are we after eight decades of debate? Quat Sci Rev 25:526-549

Tinner W, Hubschmid P, Wehrli M, Ammann B, Conedera M (1999) Long-term forest fire ecology and dynamics in southern Switzerland. J Ecol 87:273-289
Tinsley H (2001) Modern pollen deposition in traps on a transect across an anthropogenic tree-line on Exmoor, southwest England: a note summarising the first three years of data. Rev Palaeobot Palynol 117:153-158

Tonkov S, Hicks S, Bozilova E, Atanassova J (2001) Pollen monitoring in the central Rila Mountains, Southwestern Bulgaria: comparisons between pollen traps and surface samples for the period 1993-1999. Rev Palaeobot Palynol 117:167-182

Tranquillini W (1979) Physiological ecology of the Alpine timberline. Springer, Berlin

Tyler G (2001) Relationships between climate and flowering of eight herbs in a Swedish deciduous forest. Ann Bot 87:623-630

Van der Knaap WO, Ammann B (1997) Depth-age relationships of 25 well-dated Swiss Holocene pollen sequences archived in the Alpine Palynological Data-Base. Rev Paléobiol 16:433-480

Van der Knaap WO, van Leeuwen JFN (2003) Climate/pollen relationships AD 1901-1996 in two small mires near the forest limit in the northern and central Swiss Alps. Holocene 13:809-829

Van der Knaap WO, van Leeuwen JFN, Fankhauser A, Ammann B (2000) Palyno-stratigraphy of the last centuries in Switzerland based on 23 lake and mire deposits: chronostratigraphic pollen markers, regional patterns, and local histories. Rev Palaeobot Palynol 108:85-143

Van der Knaap WO, van Leeuwen JFN, Ammann B (2001a) Seven years of annual pollen influx at the forest limit in the Swiss Alps studied by pollen traps: relations to vegetation and climate. Rev Palaeobot Palynol 117:31-52

Van der Knaap WO, van Leeuwen JFN, Fankhauser A, Ammann B (2001b) Erratum to "Palyno-stratigraphy of the last centuries in Switzerland based on 23 lake and mire deposits: chronostratigraphic pollen markers, regional patterns, and local histories" [Rev Palaeobot Palynol 108 (2000) 85-142]. Rev Palaeobot Palynol 114:269-271

Welten M (1982) Vegetationsgeschichtliche Untersuchungen in den westlichen Schweizer Alpen: Bern-Wallis. Denkschr Schweiz Naturforsch Ges 95

Wick L, van Leeuwen JFN, van der Knaap WO, Lotter AF (2003) Holocene vegetation development in the catchment of Sägistalsee (1935 m asl), a small lake in the Swiss Alps. J Paleolimnol 30:261-272 